\title{
Unraveling the Role of Red:Blue LED Lights on Resource Use Efficiency and Nutritional Properties of Indoor Grown Sweet Basil
}

\author{
Giuseppina Pennisi ${ }^{1,2,3}$, Sonia Blasioli' ${ }^{1}$, Antonio Cellini' ${ }^{1}$, Lorenzo Maia ${ }^{1}$, \\ Andrea Crepaldi ${ }^{4}$, Ilaria Braschi ${ }^{1}$, Francesco Spinelli', Silvana Nicola ${ }^{2}$, \\ Juan A. Fernandez ${ }^{3}$, Cecilia Stanghellini ${ }^{5}$, Leo F. M. Marcelis ${ }^{6}$, Francesco Orsini ${ }^{1,6 *}$ and \\ Giorgio Gianquinto ${ }^{1}$
}

1 DISTAL - Department of Agricultural and Food Sciences and Technologies, Alma Mater Studiorum - Università di Bologna, Bologna, Italy, ${ }^{2}$ DISAFA-VEGMAP, Department of Agricultural, Forest and Food Sciences, University of Turin, Turin, Italy, ${ }^{3}$ Departamento de Producción Vegetal, Escuela Técnica Superior de Ingeniería Agronómica, Universidad Politécnica de Cartagena, Cartagena, Spain, ${ }^{4}$ Flytech s.r.l., Belluno, Italy, ${ }^{5}$ Wageningen UR Greenhouse Horticulture, Wageningen, Netherlands, ${ }^{6}$ Horticulture and Product Physiology Group, Wageningen University \& Research, Wageningen, Netherlands

\section{OPEN ACCESS}

Edited by:

Martine Dorais,

Laval University, Canada

Reviewed by:

Karl-Johan Bergstrand,

Swedish University of Agricultural

Sciences, Sweden

Valerie Gravel,

McGill University, Canada

*Correspondence:

Francesco Orsini

f.orsini@unibo.it

Specialty section:

This article was submitted to

Crop and Product Physiology,

a section of the journal

Frontiers in Plant Science

Received: 31 October 2018 Accepted: 26 February 2019

Published: 13 March 2019

Citation:

Pennisi G, Blasioli S, Cellini A,

Maia L, Crepaldi A, Braschi I,

Spinelli F, Nicola S, Fernandez JA,

Stanghellini C, Marcelis LFM, Orsini F and Gianquinto G (2019) Unraveling the Role of Red:Blue LED Lights on

Resource Use Efficiency and Nutritional Properties of Indoor

Grown Sweet Basil.

Front. Plant Sci. 10:305.

doi: 10.3389/fp/s.2019.00305
Indoor plant cultivation can result in significantly improved resource use efficiency (surface, water, and nutrients) as compared to traditional growing systems, but illumination costs are still high. LEDs (light emitting diodes) are gaining attention for indoor cultivation because of their ability to provide light of different spectra. In the light spectrum, red and blue regions are often considered the major plants' energy sources for photosynthetic $\mathrm{CO}_{2}$ assimilation. This study aims at identifying the role played by red:blue $(R: B)$ ratio on the resource use efficiency of indoor basil cultivation, linking the physiological response to light to changes in yield and nutritional properties. Basil plants were cultivated in growth chambers under five LED light regimens characterized by different $R$ : $B$ ratios ranging from 0.5 to 4 (respectively, $R B_{0.5}, R_{1}, R B_{2}, R B_{3}$, and $\left.\mathrm{RB}_{4}\right)$, using fluorescent lamps as control $\left(\mathrm{CK}_{1}\right)$. A photosynthetic photon flux density of $215 \mu \mathrm{mol} \mathrm{m} \mathrm{m}^{-2} \mathrm{~s}^{-1}$ was provided for $16 \mathrm{~h}$ per day. The greatest biomass production was associated with LED lighting as compared with fluorescent lamp. Despite a reduction in both stomatal conductance and PSII quantum efficiency, adoption of $\mathrm{RB}_{3}$ resulted in higher yield and chlorophyll content, leading to improved use efficiency for water and energy. Antioxidant activity followed a spectral-response function, with optimum associated with $\mathrm{RB}_{3}$. A low $\mathrm{RB}$ ratio (0.5) reduced the relative content of several volatiles, as compared to $\mathrm{CK}_{1}$ and $\mathrm{RB} \geq 2$. Moreover, mineral leaf concentration ( $\mathrm{g} \mathrm{g}^{-1} \mathrm{DW}$ ) and total content in plant ( $\mathrm{g}$ plant ${ }^{-1}$ ) were influences by light quality, resulting in greater $\mathrm{N}$, $\mathrm{P}, \mathrm{K}, \mathrm{Ca}, \mathrm{Mg}$, and Fe accumulation in plants cultivated with $\mathrm{RB}_{3}$. Contrarily, nutrient use efficiency was increased in $\mathrm{RB} \leq 1$. From this study it can be concluded that a $\mathrm{RB}$ ratio of 3 provides optimal growing conditions for indoor cultivation of basil, fostering improved performances in terms of growth, physiological and metabolic functions, and resources use efficiency.

Keywords: Ocimum basilicum L., plant factories with artificial lighting (PFALs), water use efficiency (WUE), energy use efficiency (EUE), land surface use efficiency (SUE), nutrient use efficiency (NUE) 


\section{INTRODUCTION}

Previsions on the increase of the global population (Wei and Ewing, 2018) suggest that agricultural land availability per capita ( 0.7 ha today) will decrease in the coming years (Chen et al., 2018). Agriculture nowadays uses about $70 \%$ of the world freshwater (Johnson et al., 2001) but both climate change and increase in human water use will likely result in water shortages (Elliott et al., 2014). Furthermore, the overall sustainability of current food systems is also constrained by the overuse of mineral fertilizers (Lal, 2018). As a consequence, the challenge agriculture has to face in the upcoming 50 years will be an increasing demand for food to feed ever larger cities with ever fewer resources.

In this scenario, new forms of agriculture that are not dependent on arable land and that can be developed also in the urban environment are gaining increasing popularity (Kalantari et al., 2017). Indoor farms, also called Plant Factories with Artificial Lighting (PFALs) or Vertical Farms with Artificial Lighting (VFALs), are closed plant production systems where environmental factors (e.g., temperature, humidity, light, and $\mathrm{CO}_{2}$ concentration) are controlled, minimizing the interactions with the external climate.

From a resource use perspective, VFALs present improved use efficiency of land, water, and nutrients (Graamans et al., 2018). By developing crop production in the vertical dimension, these systems can grow a higher number of plants per unit of cultivation area leading to a greater yield as compared with traditional cultivation systems (Kalantari et al., 2017). In VFALs, the adoption of hydroponics for growing plants and the possibility to recover water loss for transpiration results in up to $97 \%$ of water saving as compared to conventional agriculture (Kozai and Niu, 2016). Nutrient solution drained from the cultivation system can be recirculated avoiding runoff and leaching in soil (Dou et al., 2018). Finally, growing plants in an indoor environment enables to limit the entrance of pathogens or pests, which may allow for a pesticide-free production (Kalantari et al., 2017). To date, however, the large energy consumption associated with illumination, cooling, heating, and dehumidification, is limiting the diffusion of VFALs (Graamans et al., 2018).

From a physiological perspective, the effect of light on plant photosynthesis and growth is substantial. Specific portions of the spectrum are mostly important because the quantum yield curve presents two peaks at red and blue ranges (Inada, 1976) suggesting that they are the major energy sources for photosynthetic $\mathrm{CO}_{2}$ assimilation (Lin et al., 2013). The application of red and blue LEDs for indoor sweet basil cultivation was investigated by several researches in order to study how light quality can affect growth, photosynthetic activity, antioxidant capacity (Piovene et al., 2015; Bantis et al., 2016) and volatile profile (Carvalho et al., 2016). Nevertheless, the appropriate balance between red and blue components in the light spectrum for indoor cultivation of leafy vegetables and herbs remains unclear. The aim of this study is to identify how basil plants respond to variations in the red:blue (R:B) ratio of the incident light, providing a better understanding of physiological and biochemical adaptations set in order by the plants. The objective of the research is to foster a clearer comprehension of how functional physiological adaptations (including stomatal response and photosynthetic quantum yield efficiency) to light may be linked with changes in the plant biochemical profile (specifically for content of chlorophyll, minerals, antioxidants, and volatiles), overall leading to the definition of optimal light composition for increasing yield and resource use efficiency (e.g., water, energy, land surface, and mineral nutrition) in indoor basil cultivation.

\section{MATERIALS AND METHODS}

\section{Plant Material and Growth Conditions}

Five separate experiments were conducted in growth chambers at the Universities of Bologna (Italy) and Wageningen (Netherlands). In all experiments, basil plants belonging to the typology "Genovese" (Ocimum basilicum cv. Superbo, Sais seeds, Cesena, Italy) were used, with a planting density of 100 plants $\mathrm{m}^{-2}$ (Saha et al., 2016). During all experiments, plants were grown under artificial light only, with measured photosynthetic photon flux density (PPFD) within the growth chambers of $215 \pm 5.5 \mu \mathrm{mol}$ $\mathrm{m}^{-2} \mathrm{~s}^{-1}$, a photoperiod of $16 / 8 \mathrm{~h}$ of light/dark and air temperature of $24 \pm 2^{\circ} \mathrm{C}$, with $55-70 \%$ of relative humidity and $450 \mathrm{ppm} \mathrm{CO}_{2}$. Details on the growing systems, irrigation and fertilization management are provided in the experiment description below.

\section{Light Treatments}

In all experiments, LED lamps (Flytech s.r.l., Belluno, Italy) featuring red (peak at $669 \mathrm{~nm}$, OSRAM Hyper Red) and blue (peak at $465 \mathrm{~nm}$, OSRAM Blue) diodes (OSRAM, 2017a,b) were used. LED treatments (spectra displayed in Supplementary Figure S1) were characterized by five $R: B$ ratios, i.e., 0.5, $1,2,3$, and 4 (respectively, indicated by $R_{0.5}, R_{1}, R B_{2}$, $R B_{3}$, and $R B_{4}$ ). Specific features of all lamps are included in Table 1. Ratio between red and blue portions was calculated by defining the relative areas of the spectrum within the red $(600-700 \mathrm{~nm})$ and the blue $(400-500 \mathrm{~nm})$ regions (Singh et al., 2015). At the beginning of each experiment, lamps features were simultaneously measured as follows. Electricity absorbance $\left(W=\mathrm{J} \mathrm{s}^{-1}\right)$ was measured using a multimeter (Fluke 189, Fluke Corporation, Everett, WA, United States). Photosynthetic Photon Flux Density (PPFD, $\mu \mathrm{mol} \mathrm{m} \mathrm{m}^{-2} \mathrm{~s}^{-1}$ ) was measured using a PAR Photon Flux Sensor model QSO (Apogee instruments, Logan, UT, United States) connected with a ProCheck handheld reader, manufactured by Decagon Devices Inc. (Pullman, WA, United States). According to the instruction manual, the PAR meter has similar sensitivity to both red and blue light. Photosynthetic Photon Number Efficacy (PPNE, $\mu \mathrm{mol}$ $\mathrm{J}^{-1}$ ), an indicator of the efficacy of converting electricity into light by the lamps (i.e., the output of photons per input of electricity), was calculated as the ratio between incident PPFD and the lamp electric absorbance (Akiyama and Kozai, 2016). The junction temperature of the diode $\left(T_{\mathrm{j}}\right)$ is strongly linked with the 
TABLE 1 | Main features of the lamps used in the experiments.

\begin{tabular}{|c|c|c|c|c|c|c|c|c|c|}
\hline \multirow[t]{2}{*}{ LAMP } & \multirow[t]{2}{*}{ Model, supplier } & \multirow{2}{*}{$\begin{array}{c}\text { PPFD } \\
\left(\mu \mathrm{mol} \mathrm{m}^{-2} \mathrm{~s}^{-1}\right)\end{array}$} & \multicolumn{3}{|c|}{ Spectrum } & \multirow{2}{*}{$\begin{array}{l}\text { Energy used } \\
\qquad\left(\mathrm{W} \mathrm{m}^{-2}\right)\end{array}$} & \multirow{2}{*}{$\begin{array}{c}\text { PPNE } \\
\mu \mathrm{mol} \mathrm{J}^{-1}\end{array}$} & \multirow{2}{*}{$\begin{array}{c}T_{\mathrm{j}} \text {-Blue } \\
{ }^{\circ} \mathrm{C}\end{array}$} & \multirow{2}{*}{$\begin{array}{c}T_{\mathrm{j}} \text {-red } \\
{ }^{\circ} \mathrm{C}\end{array}$} \\
\hline & & & Red (\%) & Blue (\%) & R:B ratio & & & & \\
\hline $\mathrm{RB}_{0.5}$ & Flygrow 0.5 , Flytech & 215 & 30 & 58 & 0.5 & 154 & 1.40 & 61 & 50 \\
\hline $\mathrm{RB}_{1}$ & Flygrow $_{1}$, Flytech & 215 & 46 & 44 & 1 & 172 & 1.25 & 62 & 53 \\
\hline $\mathrm{RB}_{2}$ & Flygrow $_{2}$, Flytech & 215 & 62 & 30 & 2 & 210 & 1.02 & 65 & 65 \\
\hline $\mathrm{RB}_{3}$ & Flygrow $_{3}$, Flytech & 215 & 70 & 23 & 3 & 219 & 0.98 & 65 & 65 \\
\hline $\mathrm{RB}_{4}$ & Flygrow4 $_{4}$, Flytech & 215 & 75 & 19 & 4 & 219 & 0.98 & 65 & 70 \\
\hline $\mathrm{CK}_{1}$ & TL-D90 De Luxe 950, Philips & 215 & 29 & 31 & 1 & 386 & 0.55 & - & - \\
\hline
\end{tabular}

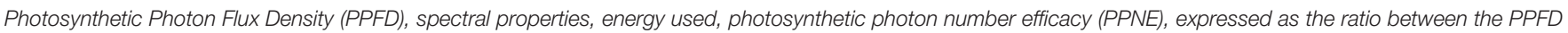
supplied $\left(\mu \mathrm{mol} \mathrm{m} \mathrm{m}^{-2} \mathrm{~s}^{-1}\right)$ and the electric energy consumed $\left(\mathrm{J} \mathrm{m}^{-2}\right)$, and calculated junction temperatures $\left(T_{j}\right)$ of the diodes are reported.

relative luminous flux emitted by the diode (Poppe, 2015). $T_{\mathrm{j}}$ was calculated as follows:

$$
T_{\mathrm{j}}=T_{\mathrm{c}}+T h R_{\mathrm{js}} * I_{\mathrm{f}} * V_{\mathrm{f}}
$$

where $T_{\mathrm{c}}$ is the measured temperature on the pad $\left(T_{\mathrm{c}}\right)$, $\mathrm{ThR}_{\mathrm{js}}$ is the thermal resistance of the LED between the junction and the solder point (feature of the LED, being $9.8 \mathrm{~K} \mathrm{~W}^{-1}$ for blue and $5.3 \mathrm{~K} \mathrm{~W}^{-1}$, OSRAM, personal communication), $I_{\mathrm{f}}$ is the current on the LED, and $V_{\mathrm{f}}$ is the direct tension on the LED. Temperature of the pad was measured using an AMPROBE 38-XRA thermometer (Amprobe, NY, United States).

\section{Experiments at Bologna University}

Four experiments were consecutively conducted in six separate compartments (each $0.64 \mathrm{~m}^{2}$ surface and $0.4 \mathrm{~m}^{3}$ volume) of a climate controlled growth chamber at the Department of Agricultural and Food Sciences (DISTAL) of Bologna University, Italy. Each compartment was sealed with light opaque walls, white painted in the internal part, and equipped with fans constantly replacing internal air (hourly exchange rate of $200 \mathrm{v}: \mathrm{v})$. Before each experiment, full randomisation of light treatments was operated.

Seeds were germinated in polystyrene containers filled with a mixture of peat $(70 \%)$ and vermiculite $(30 \%)$, under fluorescent lamps $\left(\mathrm{CK}_{1}\right.$, see specifics in Table $\left.\mathbf{1}\right)$. When plants reached the two true leaf stage (3 weeks after sowing), roots were gently washed and plantlets were transplanted into individual hydroponic systems. Each single-plant hydroponic unit was composed of an hermetically sealed plastic jar ( $1 \mathrm{~L}$ of volume), filled with a nutrient solution $(\mathrm{EC}=1.6, \mathrm{pH}=6.5)$ with the following composition: $\mathrm{N}^{-\mathrm{NO}_{3}}: 14 \mathrm{mM} ; \mathrm{N}-\mathrm{NH}_{4}: 4.4 \mathrm{mM}$; P: 1.0 mM; K: 5.0 mM; S: 2.0 mM; Ca: $1.2 \mathrm{mM}$; Mg: $5.2 \mathrm{mM}$; Fe: $17.9 \mu \mathrm{M}, \mathrm{Cu}: 2.0 \mu \mathrm{M}, \mathrm{Zn}: 3.8 \mu \mathrm{M}, \mathrm{B}: 11.6 \mu \mathrm{M}, \mathrm{Mn}$ : $18.2 \mu \mathrm{M}$, Mo: $0.5 \mu \mathrm{M}$. The nutrient solution was constantly aerated using air pumps (Airline 3, Haquoss, Turin, Italy, air exchange rate of $0.25 \mathrm{~L} \mathrm{~min}^{-1}$ pot $^{-1}$ ) and was not substituted nor replenished before harvest.

Upon transplanting, six light treatments were applied, one per each compartment. In one compartment fluorescent lamps (CK 1 , TL-D 90 De Luxe 58W, Philips, Eindhoven, Netherlands) were installed, whereas the other five chambers were equipped with lamps with variable $\mathrm{R}: \mathrm{B}$ ratio in the spectrum from 0.5 to 4 (using the lamps described in section "Light Treatments," namely
$\mathrm{RB}_{0.5}, \mathrm{RB}_{1}, \mathrm{RB}_{2}, \mathrm{RB}_{3}$, and $\left.\mathrm{RB}_{4}\right)$. Each compartment hosted 48 plants and measurements were taken in the central 9 plants. Each experiment was closed when commercial harvest was reached, at 18 Days After light Treatment (DAT), which meant 39 Days After Sowing (DAS).

\section{Experiment at Wageningen University}

One additional experiment was specifically designed to assess the PSII quantum efficiency $\left(F_{\mathrm{q}}{ }^{\prime} / F_{\mathrm{m}}{ }^{\prime}\right)$ in response to the variable rates of red and blue fractions in the spectrum. This was performed at Wageningen University (Netherlands). The experiment took place in five separated compartments (each $0.4 \mathrm{~m}^{3}$ ) inside a climate controlled growth chamber. For the entire growth cycle a standard nutrient solution $(\mathrm{EC}=2.0$, $\mathrm{pH}=6.0$ ) was used to water the plants, using the following composition: $\mathrm{N}-\mathrm{NO}_{3}: 12.4 \mathrm{mM} ; \mathrm{N}-\mathrm{NH}_{4}: 1.2 \mathrm{mM}$; P: $1.1 \mathrm{mM}$; $\mathrm{K}: 7.2 \mathrm{mM}$; S: $3.3 \mathrm{mM}$; Ca: $4.1 \mathrm{mM}$; Mg: $1.8 \mathrm{mM}$; Fe: $25 \mu \mathrm{M}$; Cu: $0.8 \mu \mathrm{M}, \mathrm{Zn}: 5 \mu \mathrm{M}, \mathrm{B}: 30 \mu \mathrm{M}, \mathrm{Mn}: 10 \mu \mathrm{M}$, Mo: $0.5 \mu \mathrm{M}$. The nutrient solution was supplied as ebb- and flow irrigation once a day in order to keep the plants well-watered at any time. Seeds were germinated in $6 \mathrm{~cm}$ pots filled with peat, under LED lamps (Greenpower led production module Deep Red/White 120, Philips, $28 \mathrm{~W}$ ). When plants reached a two true leaf stage (21 DAS), five LED light treatments were used, resembling the same conditions used in the previous experiments, varying the $\mathrm{R}: \mathrm{B}$ ratio in the spectrum from 0.5 to 4 (namely $\mathrm{RB}_{0.5}, \mathrm{RB}_{1}, \mathrm{RB}_{2}, \mathrm{RB}_{3}$, and $\mathrm{RB}_{4}$, using the same lamps manufactured by Flytech s.r.l., Belluno, Italy). Measurements of fresh yield, PSII quantum efficiency and chlorophyll were taken after 10 days of plants acclimation to the different light treatments (10 DAT), at 31 DAS.

\section{Vegetative and Physiological Measurements Growth Analysis and Resource Use Efficiency}

At harvest time, edible fresh weight (FW) of leaves and stem was measured in all experiments. Water use was individually quantified for each plant during experiments 1,2, 3, and 4 and Water Use Efficiency (WUE) was calculated by the ratio between leaf fresh yield and the volume of water used, and expressed as g FW L ${ }^{-1} \mathrm{H}_{2} \mathrm{O}$. Lighting Energy Use Efficiency (EUE) was determined according to the crop cycle length and the final leaf 
yield, related to the lamps' cumulated electricity absorption and expressed as g FW $\mathrm{kW}^{-1}$. Land Surface Use Efficiency (SUE) was determined by analyzing the potential achievable yield per unit land surface $\left(1 \mathrm{~m}^{2}\right.$, with plant density of 100 plants $\left.\mathrm{m}^{-2}\right)$ over a year (considering immediate transplanting of new plants after the harvest, resulting in 20 crop cycles each year). As for the hereby described experiments, recommended height of a layer may vary between 0.4 (Kozai, 2013; Kozai and Niu, 2016) and $0.5 \mathrm{~m}$ (Kozai, 2016). Three scenarios for SUE are therefore proposed, one on a single layer and two that consider vertical cultivation over multiple layers, representing, respectively, plant factories over 5 layers (Graamans et al., 2018) or over 10 layers (Kozai and Niu, 2016). Finally, crop Nutrient Use Efficiency (NUE) was calculated by the ratio between fresh weight and the total concentration of selected nutrients ( $\mathrm{N}, \mathrm{P}, \mathrm{K}, \mathrm{Ca}, \mathrm{Mg}$, and $\mathrm{Fe}$ ) (Benincasa et al., 2011), analyzed in leaf tissues as described below.

\section{Stomatal Conductance}

Measurements of stomatal conductance $\left(\mu \mathrm{mol} \mathrm{m} \mathrm{m}^{-2} \mathrm{~s}^{-1}\right)$ were performed on the third fully expanded leaf from the apex using a leaf porometer (AP4, Delta-T Devices, Cambridge, United Kingdom) at 18 and 11 DAT on experiments 3 and 4 , respectively.

\section{PSII Quantum Efficiency}

Measure of PSII quantum efficiency $\left(F_{\mathrm{q}}{ }^{\prime} / F_{\mathrm{m}}{ }^{\prime}\right)$ was performed in experiment 5, using a PlantExplorer ${ }^{\mathrm{TM}}$ (PhenoVation B.V., Wageningen, Netherlands), at 10 DAT (31 DAS). This parameter indicates the efficiency at which light absorbed by PSII is used for the primary quinone acceptor $\left(Q_{\mathrm{A}}\right)$ reduction. At a given photosynthetically active photon flux density, this parameter provides a rapid method to determine the PSII operating efficiency under different light spectra (Baker, 2008). The instrument was equipped with the same lamps used during the experiments (namely $\mathrm{RB}_{0.5}, \mathrm{RB}_{1}, \mathrm{RB}_{2}, \mathrm{RB}_{3}$, and $\mathrm{RB}_{4}$, Flytech s.r.l., Belluno, Italy), which were kept on before and during measurements. Measurements were performed during $1 \mathrm{~s}$, imposing an intensive light flash of $3500 \mu \mathrm{mol} \mathrm{m} \mathrm{m}^{-2} \mathrm{~s}^{-1}$ by a monochromatic red LED source (peak $660 \mathrm{~nm}$ ).

\section{Leaf Chlorophyll Content}

Leaf chlorophyll content was estimated during experiments 1, 2, 3 , and 4 at 10 DAT using a hand-held leaf chlorophyll meter (YARA N-Tester, Oslo, Norway) on the third fully expanded leaf from the apex. $N$-Tester calculates a numeric three-digit dimensionless value that is commonly expressed as $N$-Tester value (Orsini et al., 2018).

\section{Whole Plant Chlorophyll Content (Chlorophyll Index)}

Estimation of chlorophyll concentration was determined during experiment 5 through estimation of greenness using the bidirectional reflectance distribution function (BRDF) (Comar et al., 2012; Virlet et al., 2017), and obtained using PlantExplorer ${ }^{\mathrm{TM}}$ (PhenoVation B.V., Wageningen, Netherlands) at 10 DAT (31 DAS). The measures were taken while imposing a white light from a LED lamp (2700 Kelvin, $150 \mu \mathrm{mol} \mathrm{m}^{-2} \mathrm{~s}^{-1}$ ).

\section{Biochemical Determinations}

During experiments 2 and 3, basil leaf samples were immersed in liquid nitrogen and kept at $-80^{\circ} \mathrm{C}$ for biochemical analysis, whereas other samples were dried at $58^{\circ} \mathrm{C}$ for $72 \mathrm{~h}$ in a ventilated oven for elemental analysis. Dry weights were recorded at this stage. Volatile compounds analysis were performed on fresh basil leaf samples during experiment 4.

\section{Phenolic Compound Extraction}

One gram of frozen samples of basil leaves was ground with liquid nitrogen and homogenized with $4 \mathrm{~mL}$ of methanol/ $\mathrm{H}_{2} \mathrm{O}$ /acetone $(60: 30: 10 \mathrm{v} / \mathrm{v} / \mathrm{v})$ (Hartmann et al., 2008). The mixture was centrifuged (Beckman Coulter, BECKMAN, El Cajon, CA, United States) at $15,300 \times g$ for $10 \mathrm{~min}$ at $4^{\circ} \mathrm{C}$ and the supernatant was collected. The extraction was repeated twice and the final extract was used for the determination of total phenolic and flavonoid content and total antioxidant capacity.

\section{Determination of Total Phenolic and Flavonoid Contents}

Total phenolic content (TPC) was determined according to the Folin-Ciocalteu colorimetric method (Waterhouse, 2002). The total phenolic content was expressed as gallic acid equivalent in milligram per gram of fresh weight of leaves.

Total flavonoid content (TFC) was determined by aluminum chloride colorimetric assay (Zhishen et al., 1999). The results were expressed as mg of catechin equivalents per grams of fresh weight of leaves.

\section{Total Antioxidant Capacity}

Total antioxidant capacity was measured by Ferric Reducing Antioxidant Power (FRAP) assay, following methodologies from Benzie and Strain (1999) and Aaby et al. (2007). FRAP values were expressed as mmol $\mathrm{Fe}^{2+} \mathrm{kg}^{-1} \mathrm{FW}$.

\section{Nutrient Content Analysis}

To assess a nutrient balance, micro- and macro-nutrient concentrations were measured both in nutrient solutions and in basil leaves. Leaf samples to be analyzed for nutrient content were collected at harvesting during experiments 2 and 3. Nutrient solutions were also collected at both transplanting stage and at the harvest. Micro- and macronutrients analyses of nutrient solutions were performed by using an inductively coupled plasma optical emission spectrometer ICP-OES equipped with a plasma source and an optical detector with a charge-coupled device CCD (SPECTRO Analytical Instruments GmbH \& Co., Kleve, Germany), following the methodology presented in Lavrnić et al. (2018). Minerals uptake from nutrient solution was calculated by subtracting the concentration in the nutrient solution at the end of the cycle from the concentration in the fresh nutrient solution.

\section{Total Nitrogen (TN) Analysis}

Nutrient solutions (experiments 2 and 3) were analyzed for total nitrogen (TN) by using the elemental analyser Shimadzu TNM-1 (Shimadzu, Kioto, Japan). Before analysis, samples were filtered through Whatman 42 filters. TN content in dry leaf samples was measured by using a thermoelectron CHNS-O elemental analyser (Thermo Fisher 
Scientific, Waltham, MA, United States). The analysis was performed on ball-milled samples, following the methodology presented in Lavrnić et al. (2018).

\section{Volatile Organic Compound (VOCs) Analysis of Basil Leaves}

Volatile profile of basil leaves was determined in experiment 3 by gas chromatography coupled with mass spectrometry (GC-MS, QP-2010 Plus, Shimadzu, Japan), interfaced with a computerized system for data acquisition (Software GC-MS Solution V. 2.5, Shimadzu, Japan), following methodology presented in Cardenia et al. (2015). The identification of VOCs was achieved by comparing their mass spectra with those stored in the National Institute of Standards and Technology (NIST08) United States Government library and those reported in the literature. For each light treatment, GC-MS analysis was performed in triplicate using new fresh leaves as sample. Relative amounts of detected VOCs emitted by fresh basil leaves were calculated by integration of peak area followed by normalization to sample fresh weight. Data were expressed as mean of three replicates and standard deviations were calculated.

\section{Statistical Analysis}

Measures were conducted on nine plants per light treatments, which were surrounded by border plants. For the measured parameters from experiments 1,2,3, and 4, data were analyzed by two-way ANOVA (light spectrum $\times$ experiment) and the means were compared by Least Significance Difference (LSD), at 5\% significance level (Supplementary Table S1). Results from experiment 5 (fresh yield, chlorophyll index and PSII quantum efficiency) were analyzed using one-way ANOVA. Volatile compounds, measured only during experiment 3, were analyzed as the $\log _{2}$ of the relative fold change from control treatment $\left(\mathrm{CK}_{1}\right)$.

\section{RESULTS}

\section{Plant Growth and Input Use Efficiency}

During the first four experiments (those conducted at Bologna University), no significant interactions between light and experiment were observed (ANOVA results in Supplementary Table S1), therefore average values from the four experiments are used for data representation in figures and tables. Plant fresh weight was enhanced with increasing $\mathrm{RB}$ ratio, reaching the highest values at $\mathrm{RB} \geq 2$ (Figure 1A). A consistent trend in plant chlorophyll content was also evident, with the highest values found when plants were grown at $R B \geq 3$ (Figure 1B). Similar performances in terms of both yield and chlorophyll content in response to light were also evident during experiment 5 (conducted at Wageningen University), although a decrease in both yield and chlorophyll was observed at $\mathrm{RB}_{4}$ (Figures $2 \mathrm{~A}, \mathbf{B}$ ).

From a resource use perspective, water used per plant varied from $0.34\left(\mathrm{RB}_{1}\right.$ and $\left.\mathrm{CK}_{1}\right)$ to $0.42\left(\mathrm{RB}_{0.5}\right.$ and $\left.\mathrm{RB}_{4}\right)$ and 0.48 $\left(\mathrm{RB}_{2}\right.$ and $\left.\mathrm{RB}_{3}\right) \mathrm{L}_{\text {plant }}{ }^{-1}$ (data not shown). Light energy used was highest in $\mathrm{CK}_{1}$ as compared with LED treatments (Table 1). The photosynthetic photon number efficacy (PPNE) values were lower in $\mathrm{CK}_{1}$ as compared with LEDs. Moreover, the lower the fraction of red light of the LEDs the higher the efficacy (Table 1). The $T_{\mathrm{j}}$ values were of $61-65^{\circ} \mathrm{C}$ for the blue LED and $50-70^{\circ} \mathrm{C}$ for the red LED (Table 1). Accordingly, among LEDs, an increase in electricity consumption was associated with the increase in the red portion of the spectrum from 154 to $219 \mathrm{~W} \mathrm{~m}^{-2}$ (respectively, in $\mathrm{RB}_{0.5}$ and $\mathrm{RB}_{3}$ ) (Table 1 ). However, with consideration to the plant capacity to transform resources, water use efficiency (Figure 1C) was the greatest in plants grown under RB ratio of 2 or 3 (average value of $44.5 \pm 1.2 \mathrm{~g} \mathrm{FW} \mathrm{L}^{-1} \mathrm{H}_{2} \mathrm{O}$ ) and energy use efficiency (Figure 1D) was highest when $\mathrm{RB} \geq 2$ (average value of $32.7 \pm 1.0 \mathrm{~g} \mathrm{FW} \mathrm{kW}^{-1}$ ).

As evidenced by the crop yield, SUE was increased with $\mathrm{RB} \geq 2$. When the number of layers was increased to 5 and 10 vertical tiers, achievable basil yield under $R B \geq 2$ were, respectively, above 550 and $1100 \mathrm{~g} \mathrm{~m}^{-2}$ day $^{-1}$ (Figure 1E).

The greatest nutrients removal from the nutrient solution was obtained by basil plants grown under LED lighting as compared to fluorescent light, except for the calcium uptake (non-affected by light regime) and the iron uptake, that was higher in both $\mathrm{RB}_{4}$ and $\mathrm{CK}_{1}$. In the leaf tissue, concentrations presented higher values in plants grown under $\mathrm{RB}_{3}$ as compared with $\mathrm{CK}$, with exception of $\mathrm{Mg}$ that was most concentrated in leaf tissues of $\mathrm{CK}_{1}$ grown plants (Table 2 ) and $\mathrm{K}$, which presented similar values in $\mathrm{RB} \geq 3$ and $\mathrm{CK}_{1}$. No difference in $\mathrm{N}$ concentration was associated with $\mathrm{R}: \mathrm{B}$ ratio. Based on the overall mineral content per plant, $\mathrm{N}$, $\mathrm{P}, \mathrm{K}, \mathrm{Ca}, \mathrm{Mg}$, and Fe were the highest in $\mathrm{RB}_{3}$, with comparable values observed in plants grown under $\mathrm{RB}_{2}(\mathrm{~N}, \mathrm{P}, \mathrm{K}, \mathrm{Ca}$, and $\mathrm{Mg})$ or $\mathrm{RB}_{4}(\mathrm{~N}, \mathrm{~K}$, and $\mathrm{Mg})$. From a resource use perspective, NUE was the lowest when $\mathrm{CK}_{1}$ or LED lights with $\mathrm{RB} \geq 2$ were used, and this was mainly associated with higher concentrations in leaf tissue of the elements (Figure 1F).

\section{PSII Quantum Efficiency $\left(\boldsymbol{F}_{\mathrm{q}^{\prime}} / \boldsymbol{F}_{\mathrm{m}^{\prime}}\right)$}

The plant PSII quantum efficiency (measured during experiment 5) was lower with $\mathrm{RB} \geq 2$ whereas highest values were associated with $\mathrm{RB} \leq 1$ (Figure $2 \mathrm{C}$ ). The reduction in $F_{\mathrm{q}}{ }^{\prime} / F_{\mathrm{m}}{ }^{\prime}$ was also visible from the acquired plant images, where a greater number of pixels presented lowered $F_{\mathrm{q}}{ }^{\prime} / F_{\mathrm{m}}{ }^{\prime}$ values (range of $0.32-0.48$, in red), as presented in Figure 2D.

\section{Leaf Gas Exchanges}

The lowest stomatal conductance was observed in $\mathrm{RB} \geq 2$, with comparable values to $\mathrm{CK}_{1}$ and $\mathrm{RB}_{1}$ (Figure 3A). A greater presence of blue light in the spectrum (e.g., $\mathrm{RB}_{0.5}$ ) resulted in highest stomatal conductance (Figure 3A). A linear inverse relationship between stomatal conductance and water use efficiency was always observed $\left(R^{2}\right.$ of 0.69 and 0.88 in experiments 3 and 4, respectively) (Figure 3B).

\section{Antioxidant Properties}

Highest FRAP values were found in plants grown under $R_{2}$ (Figure 4A), although with comparable values to $R B \geq 3$. Total flavonoid content was highest in $\mathrm{RB}_{3}\left(1.60 \mathrm{mg} \mathrm{CE} \mathrm{g}^{-1} \mathrm{FW}\right)$, followed by $\mathrm{RB}_{1}$ and $\mathrm{RB}_{2}$ (mean value of $1.23 \mathrm{mg} \mathrm{CE} \mathrm{g}^{-1} \mathrm{FW}$ ) and by $\mathrm{RB}_{0.5}, \mathrm{RB}_{4}$, and $\mathrm{CK}_{1}$ (mean value $0.93 \mathrm{mg} \mathrm{CE} \mathrm{g}^{-1} \mathrm{FW}$ ) 

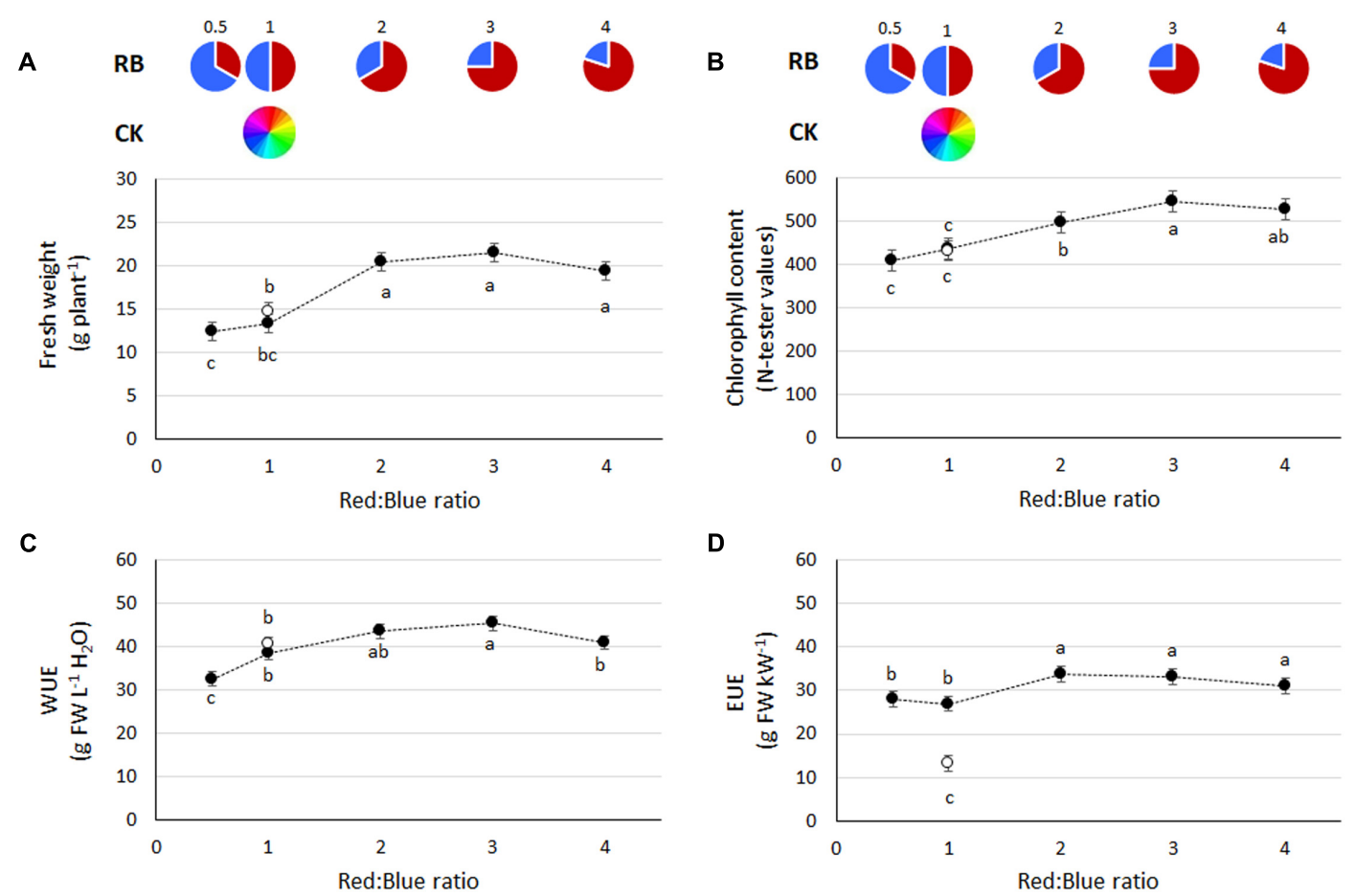

D

E
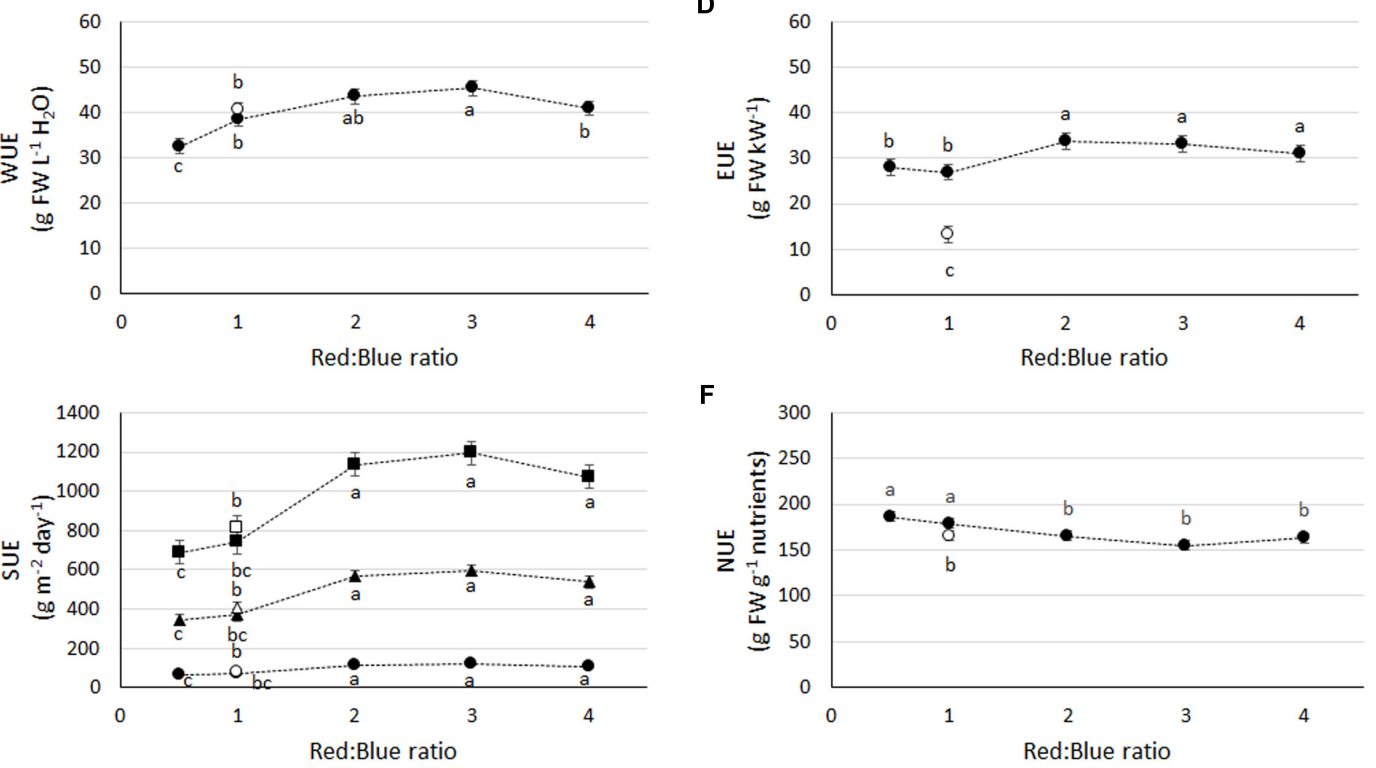

FIGURE 1 | Growth and resources use efficiency in basil plants grown under LED lights with different R:B ratio (closed symbols) or under fluorescent lights (open symbols). (A) Fresh weight, (B) chlorophyll content, (C) water use efficiency (WUE), (D) Energy Use Efficiency (EUE), (E), land Surface Use Efficiency (SUE) of a single layer (circles), or a vertical farming structure of five-layers (triangles) and ten-layers (square), and (F) overall Nutrient Use Efficiency (NUE) (based on total content of N, $\mathrm{P}, \mathrm{K}, \mathrm{Ca}, \mathrm{Mg}$, and Fe and expressed as $\mathrm{g} \mathrm{FW} \mathrm{g}{ }^{-1}$ nutrients). Data referring to experiments 1, 2, 3, and 4 (charts A-E, 36 replicate plants) and experiments 2 and 3 (chart $F, 18$ replicate plants) are indicated as mean \pm SE. Different letters indicate significant differences at $P \leq 0.05$.

(Figure 4B). No statistical differences in polyphenols content were observed in response to $\mathrm{R}: \mathrm{B}$ ratio (data not shown).

\section{Aromatic Profile}

In basil leaves, 42 VOCs were identified (Supplementary Table S2), belonging to 7 chemical classes, namely alcohols, esters, hydrocarbons, monoterpenes, phenylpropanoids, sesquiterpenes, and terpenoids. Among these, only 16 VOCs were responsible for around $90 \%$ of variations in the aromatic profile (listed in Table 3). The predominant compounds found were linalool (in all treatments except $\mathrm{RB}_{0.5}$ ), and $\alpha$-bergamotene (with greatest values observed in $\mathrm{RB} \leq 2$ ) (Table 3 ). When compared to values obtained under control light $\left(\mathrm{CK}_{1}\right), \mathrm{RB}_{0.5}$ caused a reduction in $\alpha$-pinene, $\beta$-phellandrene, myrcene, $\beta$-cis-ocimene, linalool, $\alpha$-bergamotene, humulene, $\beta$-cubebene, $\gamma$-murolene, and isoeugenol (Figure 5). On the other hand,
$\mathrm{RB} \geq 3$ presented in most cases higher or similar relative values to those measured in $\mathrm{CK}_{1}$, with the only exception of isoeugenol, which was relatively lower in all LED treated plants.

\section{DISCUSSION}

\section{Obtaining Greater Yield and Better Nutritional Properties With the Appropriate R:B Balance in the Light Spectrum}

Unraveling the optimal spectral recipe for indoor cultivation is the subject of a number of recent researches (Lin et al., 2013; Son and Oh, 2013; Piovene et al., 2015). In the present study, yield reduction was associated with an higher fraction of blue 

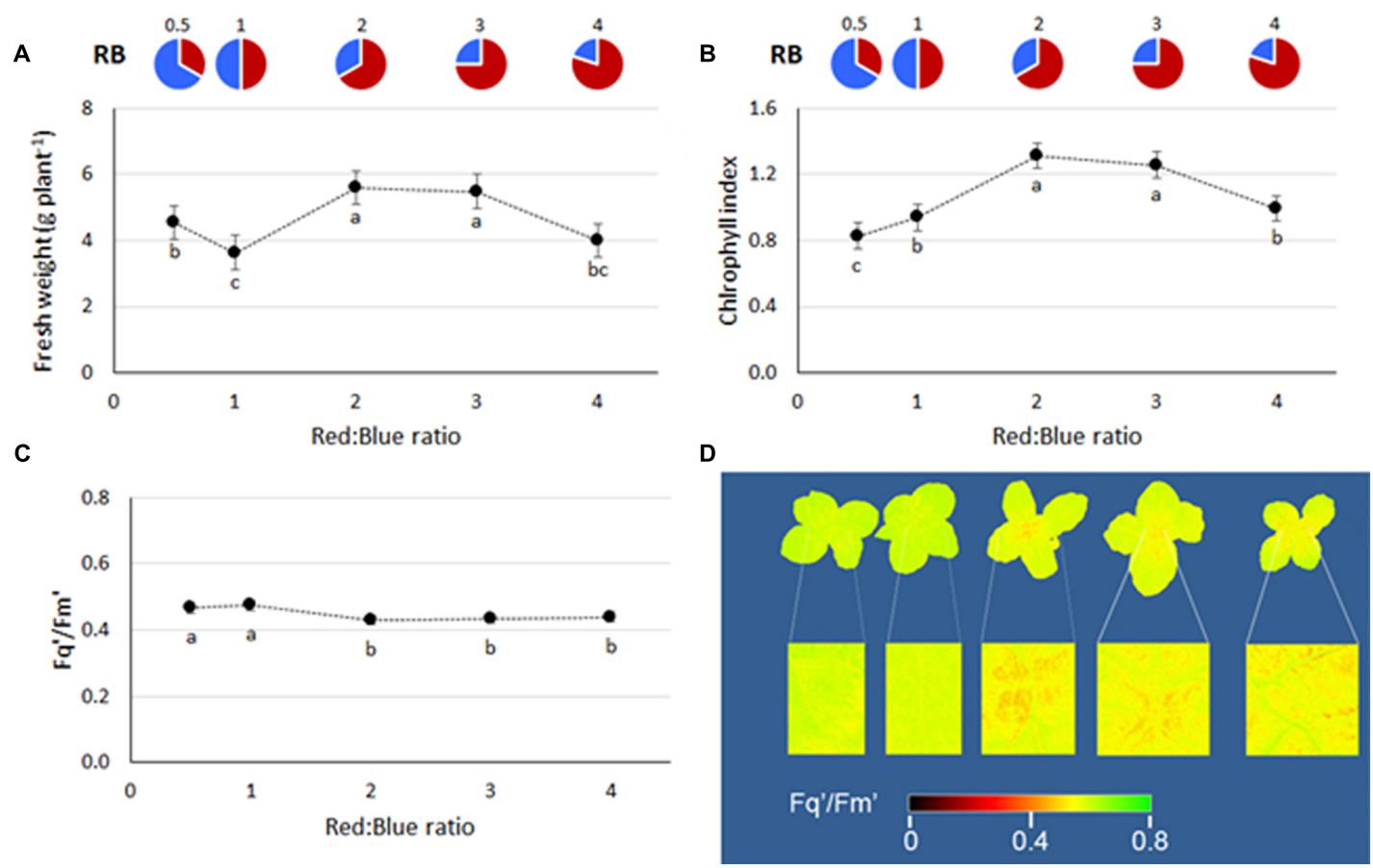

FIGURE 2 | (A) Fresh weight, (B) chlorophyll index, and (C) PSIl quantum efficiency of basil plants grown under LED lights with different R:B ratio in the spectrum $\left(\mathrm{RB}_{0.5}, \mathrm{RB}_{1}, \mathrm{RB}_{2}, \mathrm{RB}_{3}\right.$, and $\left.\mathrm{RB}_{4}\right)$. The data, referring to experiment 5 , are presented as mean values $\pm \mathrm{SE}$ (15 replicate plants). Different letters indicate significant differences at $P \leq 0.05$. In (D), whole plant images created using PlantExplorer ${ }^{\mathrm{TM}}$ are included. The greater presence of red pixels indicates lower values of $F_{\mathrm{q}}{ }^{\prime} / F_{\mathrm{m}}{ }^{\prime}$, whereas higher yellow/green areas indicate higher $F_{\mathrm{q}^{\prime}} / F_{\mathrm{m}}{ }^{\prime}$ values, as defined in the integrated legend.

TABLE 2 | Nutrient solution uptake, leaf concentration and plant content of selected mineral elements in basil grown under fluorescent light (CK 1 ) or LED lights at varying $\mathrm{R}: \mathrm{B}$ ratio $\left(\mathrm{RB}_{0.5}, \mathrm{RB}_{1}, \mathrm{RB}_{2}, \mathrm{RB}_{3}\right.$, and $\left.\mathrm{RB}_{4}\right)$.

\begin{tabular}{|c|c|c|c|c|c|c|c|c|c|c|c|c|c|c|c|c|c|c|}
\hline \multirow[b]{2}{*}{$\mathrm{RB}_{0.5}$} & \multicolumn{6}{|c|}{$\mathbf{N}$} & \multicolumn{6}{|c|}{$\mathbf{P}$} & \multicolumn{6}{|c|}{$K$} \\
\hline & 36 & c & 5.34 & $a b$ & 65.6 & $\mathrm{bc}$ & 59 & $a b$ & 1.09 & $a b$ & 13.4 & $\mathrm{bc}$ & 55 & c & 2.43 & c & 29.9 & bc \\
\hline $\mathrm{RB}_{1}$ & 34 & $\mathrm{C}$ & 5.62 & $a b$ & 86.5 & $\mathrm{~b}$ & 55 & $\mathrm{~b}$ & 0.96 & $\mathrm{bc}$ & 14.9 & $\mathrm{~b}$ & 52 & c & 2.47 & c & 38.0 & $b$ \\
\hline $\mathrm{RB}_{2}$ & 41 & bc & 5.67 & $a b$ & 121.2 & $a b$ & 56 & $b$ & 1.13 & $a b$ & 24.4 & $a b$ & 64 & b & 2.72 & $b$ & 58.9 & a \\
\hline \multirow[t]{4}{*}{$\mathrm{CK}_{1}$} & 27 & $d$ & 5.10 & $b$ & 36.0 & c & 48 & c & 0.89 & c & 6.7 & $\mathrm{C}$ & 41 & $d$ & 2.85 & $\mathbf{a}$ & 21.9 & c \\
\hline & $* * *$ & & $*$ & & $* * *$ & & *** & & $* * *$ & & $* * *$ & & $* * *$ & & $* * *$ & & $* * *$ & \\
\hline & \multicolumn{6}{|c|}{$\mathrm{Ca}$} & \multicolumn{6}{|c|}{$\mathbf{M g}$} & \multicolumn{6}{|c|}{$\mathrm{Fe}$} \\
\hline & \multicolumn{2}{|c|}{$\begin{array}{c}\text { Uptake } \\
\%\end{array}$} & \multicolumn{2}{|c|}{$\begin{array}{l}\text { Concentration } \\
\left(\mathrm{mg} \mathrm{g}^{-1} \mathrm{FW}\right)\end{array}$} & \multicolumn{2}{|c|}{$\begin{array}{c}\text { Content } \\
\left(\mathrm{mg} \mathrm{plant}^{-1}\right)\end{array}$} & \multicolumn{2}{|c|}{$\begin{array}{c}\text { Uptake } \\
\%\end{array}$} & \multicolumn{2}{|c|}{$\begin{array}{l}\text { Concentration } \\
\left(\mathrm{mg} \mathrm{g}^{-1} \mathrm{FW}\right)\end{array}$} & \multicolumn{2}{|c|}{$\begin{array}{c}\text { Content } \\
\left(\mathrm{mg} \mathrm{plant}^{-1}\right)\end{array}$} & \multicolumn{2}{|c|}{$\begin{array}{c}\text { Uptake } \\
\%\end{array}$} & \multicolumn{2}{|c|}{$\begin{array}{c}\text { Concentration } \\
\left(\mu \mathrm{g} \mathrm{g}^{-1} \mathrm{FW}\right)\end{array}$} & \multicolumn{2}{|c|}{$\begin{array}{c}\text { Content } \\
\left(\mu \text { g plant }^{-1}\right)\end{array}$} \\
\hline $\mathrm{RB}_{2}$ & 50 & & 0.92 & $\mathrm{~b}$ & 20.0 & $a b$ & 22 & $\mathrm{bc}$ & 0.69 & $\mathrm{bc}$ & 14.7 & $a b$ & 77 & b & 12.93 & b & 284.4 & b \\
\hline $\mathrm{RB}_{3}$ & 55 & & 1.06 & $\mathbf{a}$ & 26.3 & $\mathbf{a}$ & 29 & $a b$ & 0.73 & $b c$ & 18.4 & $\mathbf{a}$ & 78 & b & 17.32 & $\mathbf{a}$ & 439.4 & $\mathbf{a}$ \\
\hline $\mathrm{RB}_{4}$ & 55 & & 0.94 & $a b$ & 18.8 & b & 33 & $\mathbf{a}$ & 0.79 & $\mathrm{~b}$ & 15.2 & ab & 91 & a & 11.32 & $\mathrm{bc}$ & 230.2 & $\mathrm{bc}$ \\
\hline \multirow{2}{*}{$\mathrm{CK}_{1}$} & 52 & & 0.88 & $b$ & 6.8 & c & 22 & $\mathrm{bc}$ & 0.92 & a & 7.1 & $b$ & 91 & a & 7.76 & $c$ & 59.0 & $\mathrm{C}$ \\
\hline & ns & & $* *$ & & $* * *$ & & *** & & $* * *$ & & $* *$ & & $* * *$ & & $* * *$ & & $* * *$ & \\
\hline
\end{tabular}

Mean values from experiments 2 and 3 based on 18 replicate plants. Different letters indicate significant differences at $* P \leq 0.05,{ }^{* *} P \leq 0.01, * * * P \leq 0.001$. ns, not significant differences. Highest values are in bold. 


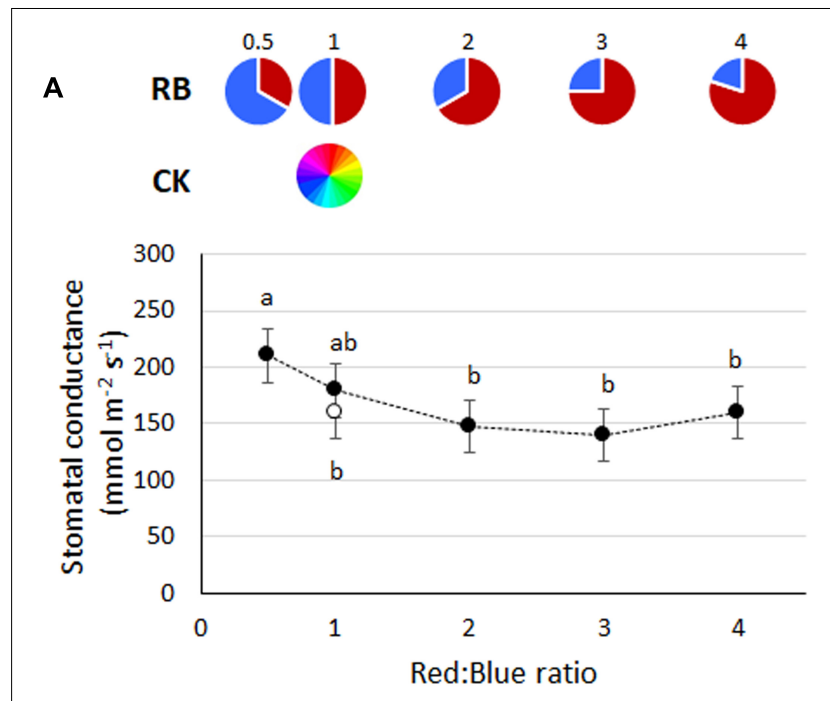

B

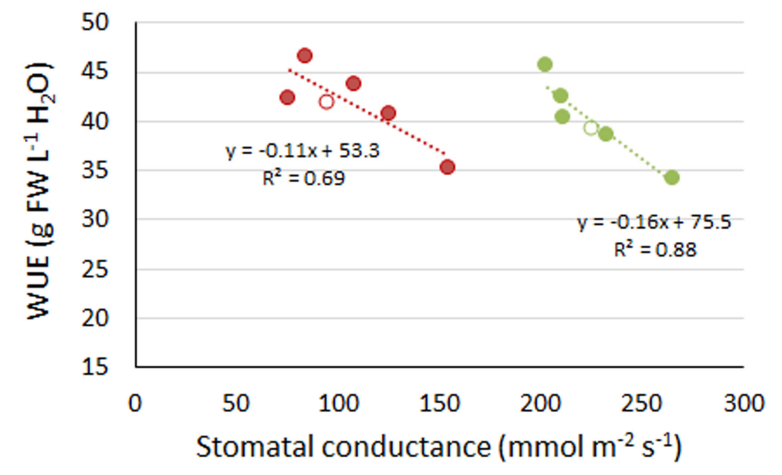

FIGURE 3 | (A) Stomatal conductance in basil plants grown under LED lights with different $R: B$ ratio in the spectrum or under fluorescent light (open symbol). Mean values (experiments 3 and 4) \pm SE (18 replicate plants). Different letters indicate significant differences at $P \leq 0.05$. (B) Linear relationship in experiment 3 (red) and experiment 4 (green) between mean values of stomatal conductance and Water Use Efficiency (WUE). Open symbols represent $\mathrm{CK}_{1}$.

light, a phenomenon that was previously associated with lower internode length and smaller leaf area (Figures 1, 2) (Yanagi et al., 1996; Ménard et al., 2006; Chen et al., 2014). Contradictory results in these terms also exist, where the presence of blue light was reported not to alter basil plant height or fresh weight (Carvalho et al., 2016; Schwend et al., 2016). However, the replicability of research results in LED lighting applications is constrained by the great variability in the experimental setups (Massa et al., 2008; Morrow, 2008), with inconsistencies in existing literature associated with differences in the growing conditions, to be related with: (a) low PPFD values (e.g., 60$120 \mu \mathrm{mol} \mathrm{m}{ }^{-2} \mathrm{~s}^{-1}$, Carvalho et al., 2016; Schwend et al., 2016), as compared with recommended values of $220 \mu \mathrm{mol} \mathrm{m} \mathrm{m}^{-2} \mathrm{~s}^{-1}$ for indoor basil production (Dou et al., 2018); (b) limited plant densities (e.g., down to 24 plants $\mathrm{m}^{-2}$, Piovene et al., 2015), as compared with common densities in hydroponics of 100 plants $\mathrm{m}^{-2}$ (Abbas, 2014); (c) changes in spectral composition (e.g., $\mathrm{R}: \mathrm{B}$ ratio of 10 and inclusion of far-red radiation, Schwend

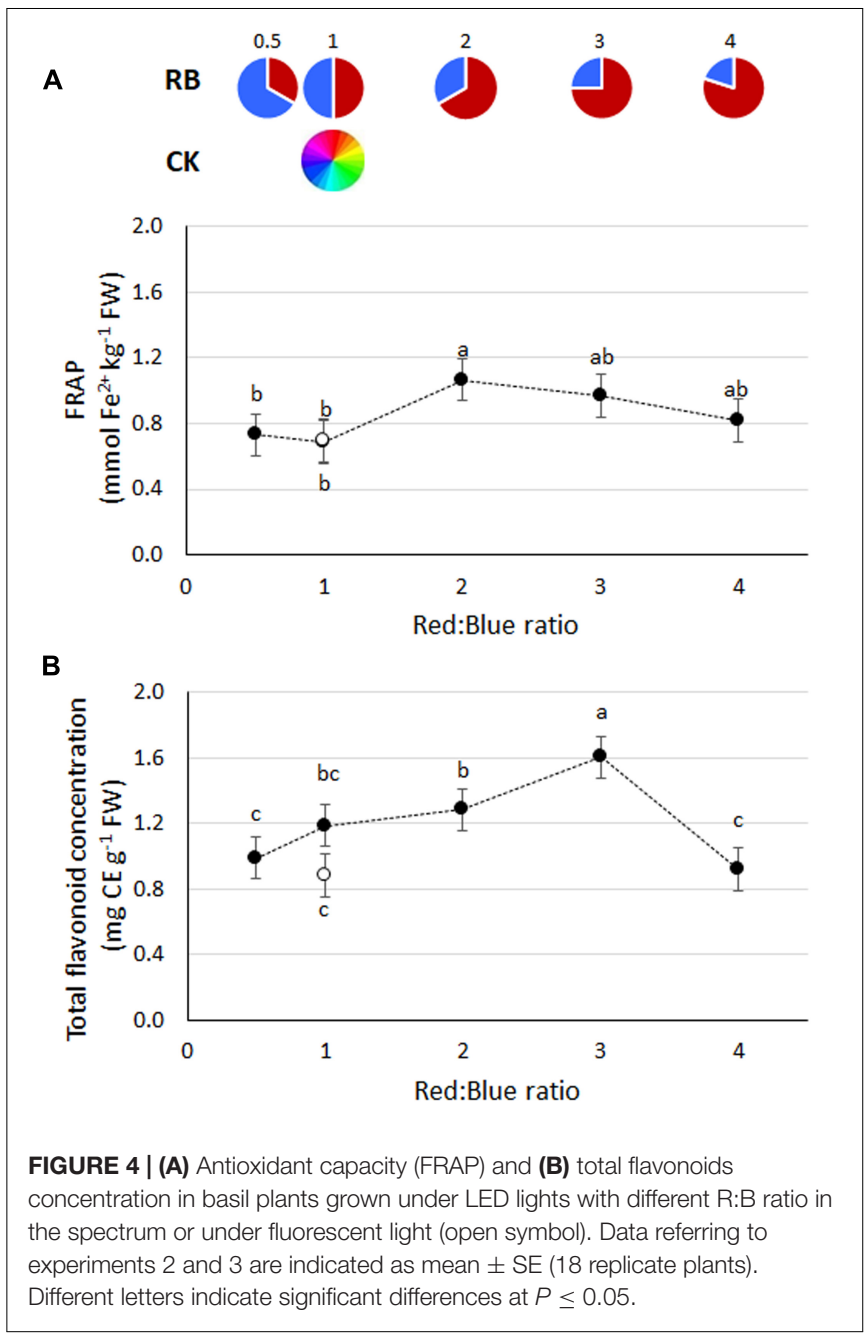

et al., 2016); (d) long cycle length (e.g., up to 100 days, Schwend et al., 2016), against common cycles of about 40 days (Dou et al., 2018).

The yield increase (Figures 1A, 2A) and the higher leaf chlorophyll concentration (Figures 1B, 2B) associated with $\mathrm{RB}_{3}$, however, were not linked with increased photosynthetic efficiency (which was instead higher on $R B \leq 1$, Figure $2 C$ ). In previous experiments, chlorophyll content was greater in LED illuminated grape leaves when red light instead of blue light was supplied (Wang et al., 2016). Similarly, a LED light supplying $\mathrm{RB}=6$ increased total chlorophyll in Chinese cabbage leaves as compared to the concentration observed in plants grown under blue or red light only (Fan et al., 2013). Moreover, in lettuce, leaf chlorophyll concentration was higher when plants were grown under a mixture of red and blue light $(R B=1)$, instead of blue or red light only (Chen et al., 2014). With regard to quantum efficiency of the PSII, experiments on cucumber (Hogewoning et al., 2010) suggested that variations in the R:B ratio have limited effects on $F_{\mathrm{q}}{ }^{\prime} / F_{\mathrm{m}}{ }^{\prime}$, although with significant decreases when the red portion was increased from $50 \%$ to 85,93 , and $100 \%$. Furthermore, it was also shown that, similarly to the experimental 
evidences hereby described, increases in the red light fraction are associated with a concurrent decrease in stomatal conductance (Hogewoning et al., 2010), whose inverse relationship with WUE in basil (Figure 3B) was also previously described (Barbieri et al., 2012). Given that photosynthetic quantum yield efficiency could only be measured in one experiment (experiment 5), the observed trend needs to be substantiated by further investigations.

Beside yield, qualitative parameters of indoor grown crops are of great relevance since they directly affect the product economic value (Kopsell and Sams, 2013; Lin et al., 2013). Light quality was reported to trigger the synthesis of secondary metabolites in herbs (Koseki et al., 2002), but so far no effects of red to blue ratio were observed in basil (Piovene et al., 2015; Carvalho et al., 2016). Similarly, no differences in FRAP, polyphenol and flavonoid content were observed in basil grown under red and blue lamps providing $\mathrm{R}: \mathrm{B}$ ratios from 0.7 to 5.5 (Piovene et al., 2015). On the other hand, red light was also shown to improve antioxidant capacity in both lettuce and basil (Samuoliene et al., 2012, 2016). In the present study, the accumulation of functional compounds, e.g., antioxidants, was achieved by modifying the light spectrum, as evidenced in the case of $\mathrm{RB}_{3}$, where values of both FRAP and flavonoid content were the highest as compared with $\mathrm{RB} \leq 1$ (Figure 4). If this is combined with the observed yield increase associated with $\mathrm{RB}_{2}$ and $\mathrm{RB}_{3}$, the amount of functional compounds achievable per plant is by far greater than in the cases of $\mathrm{RB}_{0.5}$ or $\mathrm{CK}_{1}$. These evidences support the hypothesis that, when red light increases up to $\mathrm{RB}_{3}$, photoprotective mechanisms resulted in lower photosynthetic efficiency (Hogewoning et al., 2010) and greater antioxidant biosynthesis (Samuoliene et al., 2016).

With regard to the leaf aromatic profile, $\alpha$-bergamotene (sesquiterpenes) and linalool (terpenoids) were found to be among the predominant VOCs, as for previous literature (Carvalho et al., 2016) (Table 3). The relative reduction in linalool (Figure 5) observed in $\mathrm{RB}_{0.5}$, as compared with all other treatments, could be associated with a delayed growth (Figure 1A, Carvalho et al., 2016) and the concurrent effect of abiotic stresses, such as unbalanced light supply (Loughrin and Kasperbauer, 2003; Carvalho et al., 2016). Since these measurements were only performed in experiment 3 , however, these conclusions need further investigations in order to be confirmed.

\section{The Role of Spectral Composition in the Resource Use Efficiency of Indoor Plant Cultivation \\ Water Use Efficiency}

The water saving potential associated with the adoption of protected cultivation and hydroponics is a well-established concept (Gruda, 2009; Putra and Yuliando, 2015). WUE values of traditional open field cultivation of basil were reported to be as low as $3 \mathrm{~g} \mathrm{FW} \mathrm{L}^{-1} \mathrm{H}_{2} \mathrm{O}$ in Turkey (Ekren et al., 2012). Contrarily, WUE reached 20-22 $\mathrm{g} \mathrm{FW} \mathrm{L}^{-1} \mathrm{H}_{2} \mathrm{O}$ when potted basil was grown in greenhouses in Italy (Montesano et al., 2018). In the present experiments, WUE increased up to above $45 \mathrm{~g}$ FW L L ${ }^{-1} \mathrm{H}_{2} \mathrm{O}$ in $\mathrm{RB}_{2}$ and $\mathrm{RB}_{3}$ (Figure 1C), thanks to a higher biomass production (Figure 1A) despite a slight increase in water use (data not shown). This value could possibly increase further in real VFALs, where potentially all transpired water may be recovered and re-circulated (Kozai, 2013). Beside the role of the cultivation system itself in water saving, differences were also evident among light treatments (Figure 1C). These, are to be associated with changes in the stomatal behavior (Figure 3). It is generally acknowledged that blue light (Kinoshita et al., 2001) is more effective than red light in promoting stomata opening (Shimazaki et al., 2007). Addition of blue light to background red light was reported to increase stomatal density in leaves of grape (Poudel et al., 2008), cherry tomato (XiaoYing et al., 2011), and also basil (Jensen et al., 2018). In the present study, in plants grown under $\mathrm{RB} \geq 2$, WUE was improved by $+25 \%$ (Figure 1C). Accordingly, a more effective water use by the plant was achieved through a response to the higher red light fraction in the spectrum, which led to preserved plant growth beside the induced stomatal closure (Baroli et al., 2008).

\section{Energy Use Efficiency}

The electricity cost associated with lighting is one of the main components of the production costs in VFALs (Kozai, 2013). Beside the electricity rate (that varies in each country) and the lamps efficiency to convert electricity into light, the plant capability to convert the provided radiation into effective growth will affect the VFAL sustainability. In LED lights, the photosynthetic photon number efficacy (PPNE) was reported to be between 0.5 and $2.3 \mu^{m o l ~ J^{-1}}$ (Nelson and Bugbee, 2014; Akiyama and Kozai, 2016; Park and Runkle, 2018). Alternatively, fluorescent lamps generally show a 35\% lower PPNE as compared with LED (Yano, 2016). PPNE were reported to be higher in blue LED $\left(1.9 \mu \mathrm{mol} \mathrm{J}^{-1}\right)$ as compared with red LED $(1.7 \mu \mathrm{mol}$ $\mathrm{J}^{-1}$ ) (Nelson and Bugbee, 2014). Another study (Wallace and Both, 2016), compared PPNE in LED lamps from different manufacturers, presenting values of $1.4 \mu \mathrm{mol} \mathrm{J}^{-1}$ (Valoya R150 $\left.\mathrm{NS} 1, \mathrm{RB}=2, \mathrm{PPFD}=184 \mu \mathrm{mol} \mathrm{m} \mathrm{m}^{-2} \mathrm{~s}^{-1}\right), 0.8 \mu \mathrm{mol} \mathrm{J} \mathrm{J}^{-1}$ (Orbitec LED tower, $\mathrm{RB}=3$, PPFD $=84 \mu \mathrm{mol} \mathrm{m}{ }^{-2} \mathrm{~s}^{-1}$ ) and $1.4 \mu \mathrm{mol} \mathrm{J}^{-1}$ (Cree 18W Daylight, $\mathrm{RB}=1.3$, PPFD $=4 \mu \mathrm{mol}$ $\left.\mathrm{m}^{-2} \mathrm{~s}^{-1}\right)$. PPNE was also shown to be around $1.3 \mu \mathrm{mol} \mathrm{J}{ }^{-1}$ in a red-blue top-light (Valoya AP-67, $\mathrm{RB}=3, \mathrm{PPFD}=160 \mu \mathrm{mol}$ $\mathrm{m}^{-2} \mathrm{~s}^{-1}$ ) (Särkkä et al., 2017). Nájera et al. (2018) reported PPNE to range 0.9 (Valoya AP-67, $\mathrm{RB}=3$, PPFD $=64 \mu \mathrm{mol}$ $\mathrm{m}^{-2} \mathrm{~s}^{-1}$ ) to 1.2 (Valoya AP673, RB $=5$, PPFD $=85 \mu \mathrm{mol}$ $\left.\mathrm{m}^{-2} \mathrm{~s}^{-1}\right)$, although details in the measurements performed for quantifying electricity consumption or R:B ratio were lacking. In the present experiments, PPNE increased when the fraction of blue increased. This trend may conflict with the common belief that red diodes are more efficient than blue ones in converting electricity into PAR (Schulze et al., 2014). Accordingly, red and blue LEDs (at $450 \mathrm{~mA}$ amperage), were stated to have efficiencies, respectively, of 2.3 and $1.8 \mu \mathrm{mol} \mathrm{J}^{-1}$ (Park and Runkle, 2018). Similar values were also observed in an older study (Blanken et al., 2013), with efficiencies of 2.6 (red) and 2.0 (blue) $\mu \mathrm{mol} \mathrm{J}^{-1}$ (Philips Luxeon), but once again PPNE values were based on manufacturer datasheet rather than measured in the experimental environment. The scientific explanation behind the higher efficacy of red versus blue LED is that more photons are 
TABLE 3 | Amount of main volatile compounds (mean percentage of total volatile content) in leaves of basil plants grown under fluorescent light (CK $)_{1}$ or $L E D$ lights at varying $R: B$ ratio $\left(\mathrm{RB}_{0.5}, \mathrm{RB}_{1}, \mathrm{RB}_{2}, \mathrm{RB}_{3}\right.$, and $\left.\mathrm{RB}_{4}\right)$.

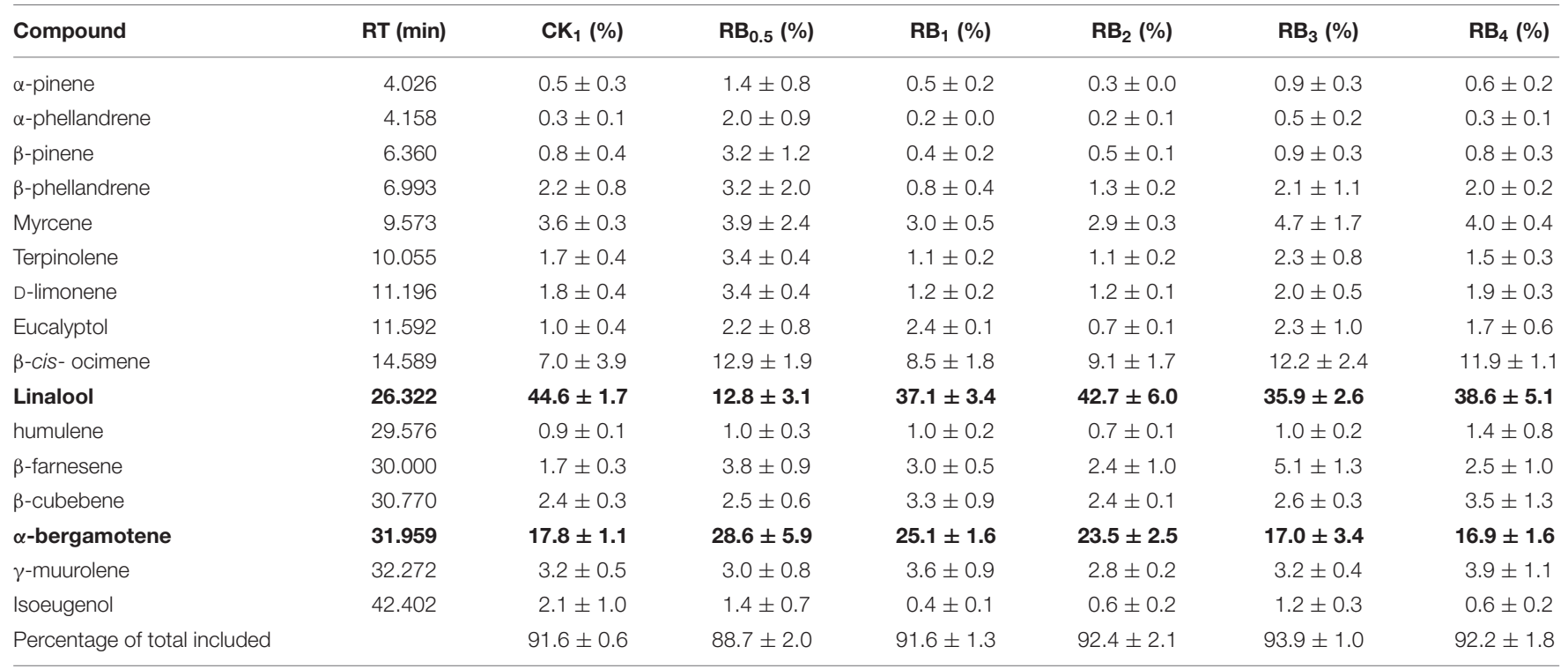

Mean values of 3 replicate plants per treatment (experiment 3) $\pm S E$. In bold, most represented volatiles.

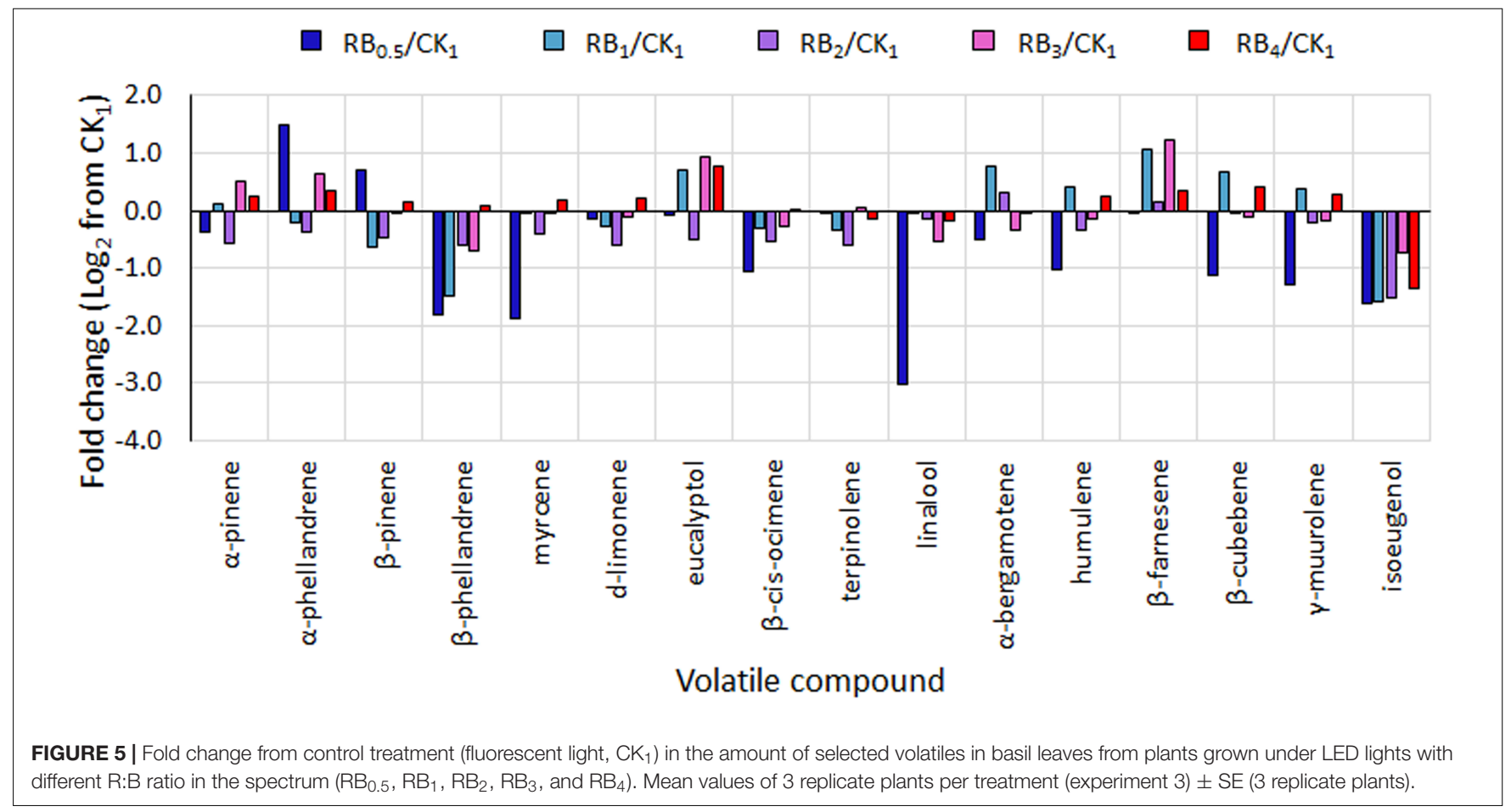

usually released by LEDs emitting at longer wavelengths (e.g., red), resulting in higher PPNE than for LEDs emitting at shorter wavelengths (e.g., blue) (Blanken et al., 2013), because blue photons are more energetic than red ones. However, as evidenced by Wang et al. (2007), the PPNE varies also in response to the use intensity of the light source and the consequential changes in its junction temperature. For instance, efficiency of red LED is reported to drop more at high temperature than that of blue, according to most LED manufacturers. Accordingly, when the temperature of LED increases from 25 to $60^{\circ} \mathrm{C}$ the light output of red and blue LEDs drops by $5-15 \%$ and 3-5\%, respectively (LUMILED, 2016, 2017; CREE, 2017). Coming to the LED used in this study, the relative radiant power at $350 \mathrm{~mA}$ decreases as temperature increases from 25 to $50-55^{\circ} \mathrm{C}(-7 \%)$ and $65-70^{\circ} \mathrm{C}$ $(-12 \%)$ in the "Hyper red" LED (peak 646-666 nm) (OSRAM, 2017b). Moreover, as temperature in the "Blue" LED (peak $464-476 \mathrm{~nm}$ ) was raised from $25^{\circ} \mathrm{C}$ to $60-65^{\circ} \mathrm{C}$, a concurrent increase in measure of $+7 \%$ in the relative luminous flux was also 
observed (OSRAM, 2017a). The decreased PPNE upon RB $\geq 1$ could therefore be associated with the observed $T_{\mathrm{j}}$ values that would have resulted in increased efficacy of blue vs. red diodes. Such variations tended to stabilize as the red portion of the spectrum increase, and PPNE was previously assumed not to vary (e.g., $\mathrm{PPNE}=2.15 \mu \mathrm{mol} \mathrm{J}{ }^{-1}$ ) when the $\mathrm{R}: \mathrm{B}$ ratio was varied (from $\mathrm{RB}=1$ to $\mathrm{RB}=2.3$, PPFD $=62.5 \mu \mathrm{mol} \mathrm{m}{ }^{-2} \mathrm{~s}^{-1}$ ) (Hernández et al., 2016) as evidenced in the present study in $\mathrm{RB} \geq 1$. However, based on the crop growth, it should be noted that the EUE was greater when higher spectral portions were allocated to the red region as for the case of $\mathrm{RB} \geq 2$ (Figure 1D), due to a larger yield increase observed in these treatments compared to $\mathrm{RB} \leq 1$.

\section{Land Surface Use Efficiency}

Increased SUE in VFALs is claimed to be from 10- to 100-folds (Kozai, 2013) higher as compared to greenhouses or open field, due to increased plant growth rates, vertical distribution of the growing system and high yields. Preliminary estimates based on application of combined mathematical models on lettuce productivity per unit cropped area, suggest that in VFALs yield would be 2.5 higher than in a greenhouse in the Netherlands (Graamans et al., 2018). Considering a vertical system (e.g., up to 10 tiers), this would allow to increase yield up to 25 -folds the values obtained in greenhouses. Limited real environment applications are to date available, however. In indoor grown basil, average plant growth rate was reported to range 1-2 $\mathrm{g} \mathrm{plant}^{-1}$ $\mathrm{d}^{-1}$ (Piovene et al., 2015), overall resembling similar values to those observed inside greenhouses (Saha et al., 2016). Growth rates in this study were consistent, ranging from $0.7(\mathrm{RB} \leq 1)$ and $0.8\left(\mathrm{CK}_{1}\right)$ to $1.2(\mathrm{RB} \geq 2) \mathrm{g} \mathrm{plant}^{-1} \mathrm{~d}^{-1}$. However, due to the elevate planting density $\left(100\right.$ plants $\left.\mathrm{m}^{-2}\right)$, when a vertical system of 5 or 10 tiers is adopted (Figure 1E), daily yield per surface of land occupied may increase up to, respectively, 567 and $1135 \mathrm{~g} \mathrm{~m}^{-2}$ day $^{-1}$, when $\mathrm{RB} \geq 2$ is used. Although potential yields may even be increased when moving from an experimental unit to a commercial plant, these figures are already impressive, if compared with previous average growth rate of about 24$110 \mathrm{~g} \mathrm{~m}^{-2} \mathrm{day}^{-1}$ recorded in traditional greenhouse production (Saha et al., 2016; Montesano et al., 2018). Moreover, such a difference may even increase due to the variability and reduction of the incident radiation as a consequence of seasonality in greenhouse grown crops.

\section{Nutrient Use Efficiency}

Similarly to the water use efficiency, NUE can be fostered by using hydroponics (Putra and Yuliando, 2015). Significant differences in nutrient uptake and accumulation among light treatments were observed (Table 2). In previous reports, the adoption of blue light in broccoli microgreen, resulted in greater accumulation of $\mathrm{P}, \mathrm{K}, \mathrm{Ca}, \mathrm{Mg}$, and $\mathrm{Fe}$ in leaf tissues as compared with plants grown under mixed red and blue $\operatorname{LED}(\mathrm{RB}=7)$, and this was associated with the increased transpirational fluxes and stomatal conductance under blue light (Kopsell and Sams, 2013). Altered fluxes of $\mathrm{Ca}$ and $\mathrm{K}$ in Arabidopsis were also associated with blue light (Babourina et al., 2002). A study on lettuce (Amoozgar et al., 2017) suggested that blue light increases accumulation of $\mathrm{K}$ and $\mathrm{Ca}$, whereas a light source providing either a red or a mixture of red and blue $(\mathrm{RB}=2)$ would result in increased level of Fe, $\mathrm{P}, \mathrm{Mg}$, and $\mathrm{N}$ accumulated in leaf tissues. Red light was also shown to increase N, P, K, and Mg uptake in lettuce (Pinho et al., 2017). On the other hand, no differences in $\mathrm{N}$ accumulation in lettuce leaves were found among monochromatic blue or red lights or mixtures of red and blue at varying ratio (e.g., $\mathrm{RB}=0.5,1,3$, and 13) (Clavijo-Herrera et al., 2018). Similarly, in this study, no differences in leaf $\mathrm{N}$ concentration was found in basil plants grown under LED regardless to the $\mathrm{R}: \mathrm{B}$ ratio adopted (Table 2). Alternatively, when incident light at $\mathrm{RB} \leq 1$ resulted in the lowest growth performances, a concurrent and greater decrease in nutrient content $\left(\mathrm{mg}\right.$ plant $^{-1}$ ) was also observed. Accordingly, an increase in NUE in measure of $+10 \%$ was observed as compared with $\mathrm{CK}_{1}$ and the other treatments $(\mathrm{RB} \geq 2)$ (Figure 1F).

\section{CONCLUSION}

Since the first LED applications in plant cultivation (Bula et al., 1991), the associated research has increased steadily, until it started to grow dramatically in recent years while vertical farms with artificial light are being implemented in NorthAmerica, Asia, and Europe (Kozai, 2015). In this new emerging sector, replicability of scientific evidences is often constrained by inconsistencies in the experimental setups, often resulting in simultaneous variations of multiple spectral parameters (e.g., including white, green, orange, and lime portions), lack of clear description of the spectral properties of the lamps used, or the adoption of limiting lighting conditions (e.g., low PPFDs). In order to build new and reliable knowledge in the sector, it is therefore crucial to implement linear and progressive research lines, allowing to identify optimal ratio among spectral components, their adaptability to the different crop phenological stages and the optimal light intensities, always paying attention to the sustainable use of resources, such as water, energy, land used, and minerals supplied. The present research can be seen as a first step toward this approach, identifying the optimal R:B ratio for sustainable indoor cultivation of sweet basil. A R:B ratio of 3 enabled to achieve highest yield, quality and resource use efficiency. In plants grown under $\mathrm{RB}_{3}$ a reduction in stomatal conductance combined with preserved plant growth resulted in increased water use efficiency. Concurrently, the higher yield associated with $\mathrm{RB}_{3}$ resulted in greater energy use efficiency, despite the reduction of PPNE observed in this treatment associated with working temperature of the lamps. On the other hand, the spectra with larger blue fractions (e.g., $\mathrm{RB} \leq 1$ ) resulted in lower yield and chlorophyll content, altogether with inefficiencies in water, energy and land surface use. Preliminary results on both photosynthetic quantum yield efficiency and volatile contents were also associated with changes in the light spectral composition, although further researches would be needed in order to confirm the observed trends. Starting from the promising results associated with $\mathrm{RB}_{3}$, future researches should target the effect of additional spectral regions, the identification of crop intra- and inter-specific variability in the response, as well as the definition of optimal light intensities. 
Crop management practices can also be addressed, e.g., adapting irrigation or fertilization plans to plant needs as they are affected by light quality.

\section{AUTHOR CONTRIBUTIONS}

GP designed and performed all experiments and drafted the manuscript. FO contributed to the experimental design and the drafting of the manuscript. SB and IB performed analyses of volatiles and nutrients and revised the manuscript. ACe and FS performed the analyses of antioxidants, contributed to the statistical analysis and revised the manuscript. LoM contributed to the experimental setup and performed measurements on energy use efficiency. ACr coordinated the manufacturing of the lamps used in the experiments. CS and LeM contributed to the experiments on PSII quantum efficiency and supported drafting the manuscript. SN, JF, and GG critically revised the manuscript.

\section{REFERENCES}

Aaby, K., Wrolstad, R. E., Ekeberg, D., and Skrede, G. (2007). Polyphenol composition and antioxidant activity in strawberry purees; impact of achene level and storage. J. Agric. Food Chem. 55, 5156-5166. doi: 10.1021/jf070467u

Abbas, M. S. (2014). Assessment of density and cultivation type on growth and yield of two cultivars of basil (Ocimum basilicum, L.). Int. J. Agronomy Agric. Res. 5, 74-79.

Akiyama, T., and Kozai, T. (2016). "Light environment in the cultivation space of plant factory with LEDs," in LED Lighting for Urban Agriculture, ed. S. Dutta Gupta (Singapore: Springer Nature), 91-109. doi: 10.1007/978-981-101848-0_7

Amoozgar, A., Mohammadi, A., and Sabzalian, M. R. (2017). Impact of lightemitting diode irradiation on photosynthesis, phytochemical composition and mineral element content of lettuce cv. Grizzly. Photosynthetica 55, 85-95. doi: 10.1007/s11099-016-0216-8

Babourina, O., Newman, I., and Shabala, S. (2002). Blue light-induced kinetics of $\mathrm{H}+$ and $\mathrm{Ca} 2+$ fluxes in etiolated wild-type and phototropin-mutant Arabidopsis seedlings. Proc. Natl. Acad. Sci. U.S.A. 99, 2433-2438. doi: 10.1073/ pnas.042294599

Baker, N. R. (2008). Chlorophyll fluorescence: a probe of photosynthesis in vivo. Ann. Rev. Plant Biol. 59, 89-113. doi: 10.1146/annurev.arplant.59.032607. 092759

Bantis, F., Ouzounis, T., and Radoglou, K. (2016). Artificial LED lighting enhances growth characteristics and total phenolic content of Ocimum basilicum, but variably affects transplant success. Sci. Hortic. 198, 277-283. doi: 10.1016/j. scienta.2015.11.014

Barbieri, G., Vallone, S., Orsini, F., Paradiso, R., De Pascale, S., Negre-Zakharov, F., et al. (2012). Stomatal density and metabolic determinants mediate salt stress adaptation and water use efficiency in basil (Ocimum basilicum L.). J. Plant Physiol. 169, 1737-1746. doi: 10.1016/j.jplph.2012.07.001

Baroli, I., Price, G. D., Badger, M. R., and von Caemmerer, S. (2008). The contribution of photosynthesis to the red light response of stomatal conductance. Plant Physiol. 146, 737-747. doi: 10.1104/pp.107.110924

Benincasa, P., Guiducci, M., and Tei, F. (2011). The nitrogen use efficiency: meaning and sources of variation-case studies on three vegetable crops in central Italy. HortTechnology 21, 266-273. doi: 10.21273/HORTTECH.21.3.266

Benzie, I. F., and Strain, J. J. (1999). [2] Ferric reducing/antioxidant power assay: direct measure of total antioxidant activity of biological fluids and modified version for simultaneous measurement of total antioxidant power and ascorbic acid concentration. Methods Enzymol. 299, 15-27. doi: 10.1016/S0076-6879(99) 99005-5

\section{ACKNOWLEDGMENTS}

The conduction of the experiment on plant photosynthetic efficiency has been made possible by a stay of FO within the Department of Plant Sciences, Wageningen, financed by a grant of the C. T. de Wit Graduate School for Production Ecology and Resource Conservation (PE\&RC) of Wageningen University. We acknowledge Dr. E. Kaiser (WUR) and V. Jalink (Phenovation B.V., Wageningen) for their support in the implementation of the experiment on PSII quantum efficiency. We are also grateful to Prof. M. T. Rodriguez-Estrada, Dr. V. Cardenia, and Mr. S. Savioli for their technical support in GC-MS analysis.

\section{SUPPLEMENTARY MATERIAL}

The Supplementary Material for this article can be found online at: https://www.frontiersin.org/articles/10.3389/fpls.2019.00305/ full\#supplementary-material

Blanken, W., Cuaresma, M., Wijffels, R. H., and Janssen, M. (2013). Cultivation of microalgae on artificial light comes at a cost. Algal Res. 2, 333-340. doi: 10.1016/j.algal.2013.09.004

Bula, R. J., Morrow, R. C., Tibbitts, T. W., Barta, D. J., Ignatius, R. W., and Martin, T. S. (1991). Light-emitting diodes as a radiation source for plants. HortScience 26, 203-205. doi: 10.21273/HORTSCI.26.2.203

Cardenia, V., Olivero, G., and Rodriguez-Estrada, M. T. (2015). Thermal oxidation of cholesterol: preliminary evaluation of 2-methyl-6-heptanone and 3-methylbutanal as volatile oxidation markers. Steroids 99, 161-171. doi: 10. 1016/j.steroids.2015.03.017

Carvalho, S. D., Schwieterman, M. L., Abrahan, C. E., Colquhoun, T. A., and Folta, K. M. (2016). Light quality dependent changes in morphology, antioxidant capacity, and volatile production in sweet basil (Ocimum basilicum). Front. Plant Sci. 7:1328. doi: 10.3389/fpls.2016.01328

Chen, B., Han, M. Y., Peng, K., Zhou, S. L., Shao, L., Wu, X. F., et al. (2018). Global land-water nexus: agricultural land and freshwater use embodied in worldwide supply chains. Sci. Total Environ. 613, 931-943. doi: 10.1016/j.scitotenv.2017. 09.138

Chen, X. L., Guo, W. Z., Xue, X. Z., Wang, L. C., and Qiao, X. J. (2014). Growth and quality responses of 'Green Oak Leaf' lettuce as affected by monochromic or mixed radiation provided by fluorescent lamp (FL) and light-emitting diode (LED). Sci. Hortic. 172, 168-175. doi: 10.1016/j.scienta.2014.04.009

Clavijo-Herrera, J., van Santen, E., and Gómez, C. (2018). Growth, water-use efficiency, stomatal conductance, and nitrogen uptake of two lettuce cultivars grown under different percentages of blue and red light. Horticulturae 4:16. doi: 10.3390/horticulturae4030016

Comar, A., Burger, P., de Solan, B., Baret, F., Daumard, F., and Hanocq, J. F. (2012) A semi-automatic system for high throughput phenotyping wheat cultivars infield conditions: description and first results. Funct. Plant Biol. 39, 914-924. doi: $10.1071 /$ FP12065

CREE (2017). CLD-DS18 Rev 25C. Product Family Data Sheet. Durham, NC: CREE.

Dou, H., Niu, G., Gu, M., and Masabni, J. G. (2018). Responses of sweet basil to different daily light integrals in photosynthesis, morphology, yield, and nutritional quality. HortScience 53, 496-503. doi: 10.21273/HORTSCI12785-17

Ekren, S., Sönmez, Ç, Özçakal, E., Kurttaş, Y. S. K., Bayram, E., and Gürgülü, H. (2012). The effect of different irrigation water levels on yield and quality characteristics of purple basil (Ocimum basilicum L.). Agric. Water Manag. 109, 155-161. doi: 10.1016/j.agwat.2012.03.004

Elliott, J., Deryng, D., Müller, C., Frieler, K., Konzmann, M., Gerten, D., et al. (2014). Constraints and potentials of future irrigation water availability on agricultural production under climate change. Proc. Natl. Acad. Sci. U.S.A. 111, 3239-3244. doi: 10.1073/pnas.1222474110 
Fan, X., Zang, J., Xu, Z., Guo, S., Jiao, X., Liu, X., et al. (2013). Effects of different light quality on growth, chlorophyll concentration and chlorophyll biosynthesis precursors of non-heading Chinese cabbage (Brassica campestris L.). Acta Physiol. Plant. 35, 2721-2726. doi: 10.1007/s11738-013-1304- z

Graamans, L., Baeza, E., Van Den Dobbelsteen, A., Tsafaras, I., and Stanghellini, C. (2018). Plant factories versus greenhouses: comparison of resource use efficiency. Agric. Syst. 160, 31-43. doi: 10.1016/j.agsy.2017.11.003

Gruda, N. (2009). Do soilless culture systems have an influence on product quality of vegetables? J. Appl. Bot. Food Qual. 82, 141-147.

Hartmann, A., Patz, C. D., Andlauer, W., Dietrich, H., and Ludwig, M. (2008). Influence of processing on quality parameters of strawberries. J. Agric. Food Chem. 56, 9484-9489. doi: 10.1021/jf801555q

Hernández, R., Eguchi, T., Deveci, M., and Kubota, C. (2016). Tomato seedling physiological responses under different percentages of blue and red photon flux ratios using LEDs and cool white fluorescent lamps. Sci. Hortic. 213, 270-280. doi: 10.1016/j.scienta.2016.11.005

Hogewoning, S. W., Trouwborst, G., Maljaars, H., Poorter, H., van Ieperen, W., and Harbinson, J. (2010). Blue light dose-responses of leaf photosynthesis, morphology, and chemical composition of Cucumis sativus grown under different combinations of red and blue light. J. Exp. Bot. 61, 3107-3117. doi: $10.1093 /$ jxb/erq132

Inada, K. (1976). Action spectra for photosynthesis in higher plants. Plant Cell Physiol. 17, 355-365. doi: 10.1093/oxfordjournals.pcp.a075288

Jensen, N. B., Clausen, M. R., and Kjaer, K. H. (2018). Spectral quality of supplemental LED grow light permanently alters stomatal functioning and chilling tolerance in basil (Ocimum basilicum L.). Sci. Hortic. 227, 38-47. doi: 10.1016/j.scienta.2017.09.011

Johnson, N., Revenga, C., and Echeverria, J. (2001). Managing water for people and nature. Science 292, 1071-1072. doi: 10.1126/science.1058821

Kalantari, F., Mohd Tahir, O., Mahmoudi Lahijani, A., and Kalantari, S. (2017). A review of vertical farming technology: a guide for implementation of building integrated agriculture in cities. Adv. Eng. Forum 24, 76-91. doi: 10.4028/www. scientific.net/AEF.24.76

Kinoshita, T., Doi, M., Suetsugu, N., Kagawa, T., Wada, M., and Shimazaki, K. I. (2001). Phot 1 and phot 2 mediate blue light regulation of stomatal opening. Nature 414, 656-660. doi: 10.1038/414656a

Kopsell, D. A., and Sams, C. E. (2013). Increases in shoot tissue pigments, glucosinolates, and mineral elements in sprouting broccoli after exposure to short-duration blue light from light emitting diodes. J. Am. Soc. Hortic. Sci. 138, 31-37. doi: 10.21273/JASHS.138.1.31

Koseki, P. M., Villavicencio, A. L. C., Brito, M. S., Nahme, L. C., Sebastião, K. I., Rela, P. R., et al. (2002). Effects of irradiation in medicinal and eatable herbs. Radiat. Phys. Chem. 63, 681-684. doi: 10.1016/S0969-806X(01) 00658-2

Kozai, T. (2013). Resource use efficiency of closed plant production system with artificial light: concept, estimation and application to plant factory. Proc. Jpn. Acad. B 89, 447-461. doi: 10.2183/pjab.89.447

Kozai, T. (2015). "PFAL business and R\&D in the world: current status and perspectives," in Plant Factory: An Indoor Vertical Farming System for Efficient Quality Food Production, eds T. Kozai, G. Niu, and M. Takagaki (Cambridge, MA: Academic Press), 35-68.

Kozai, T. (2016). "Plant production process, floor plan, and layout of PFAL", in Plant Factory: An Indoor Vertical Farming System for Efficient Quality Food Production, eds T. Kozai, G. Niu, and M. Takagaki (Cambridge, MA: Academic Press), 203-212.

Kozai, T., and Niu, G. (2016). "Plant factory as a resource-efficient closed plant production system," in Plant Factory: An Indoor Vertical Farming System for Efficient Quality Food Production, eds T. Kozai, G. Niu, and M. Takagaki (Cambridge, MA: Academic Press), 69-90.

Lal, R. (2018). Saving global land resources by enhancing eco-efficiency of agroecosystems. J. Soil Water Cons. 73, 100A-106A. doi: 10.2489/jswc.73.4. $100 \mathrm{~A}$

Lavrnić, S., Braschi, I., Anconelli, S., Blasioli, S., Solimando, D., Mannini, P., et al. (2018). Long-term monitoring of a surface flow constructed wetland treating agricultural drainage water in northern Italy. Water 10:644. doi: 10. 3390/w10050644

Lin, K. H., Huang, M. Y., Huang, W. D., Hsu, M. H., Yang, Z. W., and Yang, C. M. (2013). The effects of red, blue, and white light-emitting diodes on the growth, development, and edible quality of hydroponically grown lettuce (Lactuca sativa L. var. capitata). Sci. Hortic. 150, 86-91. doi: 10.1016/j.scienta.2012.10.002 Loughrin, J. H., and Kasperbauer, M. J. (2003). Aroma content of fresh basil (Ocimum basilicum $\mathrm{L}$.) leaves is affected by light reflected from colored mulches. J. Agric. Food Chem. 51, 2272-2276. doi: 10.1021/jf021076c

LUMILED (2016). DS146 LUXEON 3535L Color Line Product Datasheet. Amsterdam: LUMILED.

LUMILED (2017). DS171 LUXEON SunPlus Series for Horticulture Product Datasheet. Amsterdam: LUMILED.

Massa, G. D., Kim, H. H., Wheeler, R. M., and Mitchell, C. A. (2008). Plant productivity in response to LED lighting. HortScience 43, 1951-1956. doi: 10. 21273/HORTSCI.43.7.1951

Ménard, C., Dorais, M., Hovi, T., and Gosselin, A. (2006). Developmental and physiological responses of tomato and cucumber to additional blue light. Acta Hortic. 711, 291-296. doi: 10.17660/ActaHortic.2006.711.39

Montesano, F. F., van Iersel, M. W., Boari, F., Cantore, V., D'Amato, G., and Parente, A. (2018). Sensor-based irrigation management of soilless basil using a new smart irrigation system: effects of set-point on plant physiological responses and crop performance. Agric. Water Manag. 203, 20-29. doi: 10.1016/ j.agwat.2018.02.019

Morrow, R. C. (2008). LED lighting in horticulture. HortScience 43, 1947-1950. doi: 10.21273/HORTSCI.43.7.1947

Nájera, C., Guil-Guerrero, J. L., Enríquez, L. J., Álvaro, J. E., and Urrestarazu, M. (2018). LED-enhanced dietary and organoleptic qualities in postharvest tomato fruit. Postharv. Biol. Technol. 145, 151-156. doi: 10.1016/j.postharvbio.2018.07. 008

Nelson, J. A., and Bugbee, B. (2014). Economic analysis of greenhouse lighting: light emitting diodes vs. high intensity discharge fixtures. PLoS One 9:e99010. doi: 10.1371/journal.pone.0099010

Orsini, F., Pennisi, G., Mancarella, S., Al Nayef, M., Sanoubar, R., Nicola, S., et al. (2018). Hydroponic lettuce yields are improved under salt stress by utilizing white plastic film and exogenous applications of proline. Sci. Hortic. 233, 283-293. doi: 10.1016/j.scienta.2018.01.019

OSRAM (2017a). OSLON SSL 80 Datasheet Version 1.0. GB CS8PM1.13. Munich: OSRAM.

OSRAM (2017b). OSLON SSL 89 Datasheet Version 2.0. GB CS8PM1.24. Munich: OSRAM.

Park, Y., and Runkle, E. S. (2018). Spectral effects of light-emitting diodes on plant growth, visual color quality, and photosynthetic photon efficacy: white versus blue plus red radiation. PLoS One 13:e0202386. doi: 10.1371/journal. pone.0202386

Pinho, P., Jokinen, K., and Halonen, L. (2017). The influence of the LED light spectrum on the growth and nutrient uptake of hydroponically grown lettuce. Lighting Res. Technol. 49, 866-881. doi: 10.1177/1477153516642269

Piovene, C., Orsini, F., Bosi, S., Sanoubar, R., Bregola, V., Dinelli, G., et al. (2015). Optimal red: blue ratio in led lighting for nutraceutical indoor horticulture. Sci. Hortic. 193, 202-208. doi: 10.1016/j.scienta.2015.07.015

Poppe, A. (2015). Multi-domain compact modeling of LEDs: an overview of models and experimental data. Microelectron. J. 46, 1138-1151. doi: 10.1016/ j.mejo.2015.09.013

Poudel, P. R., Kataoka, I., and Mochioka, R. (2008). Effect of red-and blue-lightemitting diodes on growth and morphogenesis of grapes. Plant Cell Tissue Org. Cult. 92, 147-153. doi: 10.1007/s11240-007-9317-1

Putra, P. A., and Yuliando, H. (2015). Soilless culture system to support water use efficiency and product quality: a review. Agric. Agric. Sci. Procedia 3, 283-288. doi: 10.1016/j.aaspro.2015.01.054

Saha, S., Monroe, A., and Day, M. R. (2016). Growth, yield, plant quality and nutrition of basil (Ocimum basilicum L.) under soilless agricultural systems. Ann. Agric. Sci. 61, 181-186. doi: 10.1016/j.aoas.2016.10.001

Samuolienè, G., Brazaitytė, A., Viršilè, A., Jankauskienė, J., Sakalauskienè, S., and Duchovskis, P. (2016). Red light-dose or wavelength-dependent photoresponse of antioxidants in herb microgreens. PLoS One 11:e0163405. doi: 10.1371/ journal.pone. 0163405

Samuolienè, G., Sirtautas, R., Brazaitytè, A., and Duchovskis, P. (2012). LED lighting and seasonality effects antioxidant properties of baby leaf lettuce. Food Chem. 134, 1494-1499. doi: 10.1016/j.foodchem.2012.03.061

Särkkä, L. E., Jokinen, K., Ottosen, C. O., and Kaukoranta, T. (2017). Effects of HPS and LED lighting on cucumber leaf photosynthesis, light quality penetration 
and temperature in the canopy, plant morphology and yield. Agric. Food Sci. 26, 102-110. doi: 10.23986/afsci.60293

Schulze, P. S., Barreira, L. A., Pereira, H. G., Perales, J. A., and Varela, J. C. (2014). Light emitting diodes (LEDs) applied to microalgal production. Trends Biotechnol. 32, 422-430. doi: 10.1016/j.tibtech.2014.06.001

Schwend, T., Prucker, D., Peisl, S., Nitsopoulos, A., and Mempel, H. (2016). The rosmarinic acid content of basil and borage correlates with the ratio of red and far-red light. Eur. J. Hortic. Sci. 81, 243-247. doi: 10.17660/eJHS.2016/81.5.2

Shimazaki, K. I., Doi, M., Assmann, S. M., and Kinoshita, T. (2007). Light regulation of stomatal movement. Annu. Rev. Plant Biol. 58, 219-247. doi: 10.1146/annurev.arplant.57.032905.105434

Singh, D., Basu, C., Meinhardt-Wollweber, M., and Roth, B. (2015). LEDs for energy efficient greenhouse lighting. Renew. Sust. Energ. Rev. 49, 139-147. doi: $10.1016 /$ j.rser.2015.04.117

Son, K. H., and Oh, M. M. (2013). Leaf shape, growth, and antioxidant phenolic compounds of two lettuce cultivars grown under various combinations of blue and red light-emitting diodes. HortScience 48, 988-995. doi: 10.21273/ HORTSCI.48.8.988

Virlet, N., Sabermanesh, K., Sadeghi-Tehran, P., and Hawkesford, M. J. (2017). Field Scanalyzer: an automated robotic field phenotyping platform for detailed crop monitoring. Funct. Plant Biol. 44, 143-153. doi: 10.1071/ FP12065

Wallace, C., and Both, A. J. (2016). Evaluating operating characteristics of light sources for horticultural applications. Acta Hortic. 1134, 435-444. doi: 10. 17660/ActaHortic.2016.1134.55

Wang, C. Y., Fu, C. C., and Liu, Y. C. (2007). Effects of using light-emitting diodes on the cultivation of Spirulina platensis. Biochem. Eng. J. 37, 21-25. doi: 10.1016/j.bej.2007.03.004

Wang, S., Wang, X., Shi, X., Wang, B., Zheng, X., Wang, H., et al. (2016). Red and blue lights significantly affect photosynthetic properties and ultrastructure of mesophyll cells in senescing grape leaves. Hortic. Plant J. 2, 82-90. doi: 10.1016/j.hpj.2016.03.001
Waterhouse, A. L. (2002). "Determination of total phenolics," in Current Protocols in Food Analytical Chemistry, ed. R. E. Wrolstad (New York, NY: John Wiley \& Sons), I1.1.1-I1.1.8.

Wei, Y. D., and Ewing, R. (2018). Urban expansion, sprawl and inequality. Landsc. Urban Plan. 177, 259-265. doi: 10.1016/j.landurbplan.2018.05.021

XiaoYing, L., ShiRong, G., ZhiGang, X., XueLei, J., and Tezuka, T. (2011). Regulation of chloroplast ultrastructure, cross-section anatomy of leaves, and morphology of stomata of cherry tomato by different light irradiations of lightemitting diodes. HortScience 46, 217-221. doi: 10.21273/HORTSCI.46.2.217

Yanagi, T., Okamoto, K., and Takita, S. (1996). Effect of blue, red, and blue/red lights of two different PPF levels on growth and morphogenesis of lettuce plants. Acta Hortic. 440, 117-122. doi: 10.17660/ActaHortic.1996.440.21

Yano, A. (2016). "Energy balance and energy conversion process of LEDs and LED lighting systems," in LED Lighting for Urban Agriculture, ed. S. Dutta Gupta (Singapore: Springer Nature), 417-427.

Zhishen, J., Mengcheng, T., and Jianming, W. (1999). The determination of flavonoid contents in mulberry and their scavenging effects on superoxide radicals. Food Chem. 64, 555-559. doi: 10.1016/S0308-8146(98)00102-2

Conflict of Interest Statement: ACr was employed by company Flytech s.r.l.

The remaining authors declare that the research was conducted in the absence of any commercial or financial relationships that could be construed as a potential conflict of interest.

Copyright ( 2019 Pennisi, Blasioli, Cellini, Maia, Crepaldi, Braschi, Spinelli, Nicola, Fernandez, Stanghellini, Marcelis, Orsini and Gianquinto. This is an open-access article distributed under the terms of the Creative Commons Attribution License (CC BY). The use, distribution or reproduction in other forums is permitted, provided the original author(s) and the copyright owner(s) are credited and that the original publication in this journal is cited, in accordance with accepted academic practice. No use, distribution or reproduction is permitted which does not comply with these terms. 